\title{
A new Encephalarteae trunk (Cycadales) from the Cretaceous of Patagonia (Mata Amarilla Formation, Austral Basin), Argentina
}

\author{
L.C.A. Martínez ${ }^{\text {a, b, * }}$, A. Iglesias ${ }^{\text {c }}$, A.E. Artabe ${ }^{\text {b }}$, A.N. Varela ${ }^{\text {d }}$, S. Apesteguía ${ }^{\text {e }}$ \\ a Instituto de Botánica Darwinion (ANCEFN - CONICET), Labardén 200, CC22, B1642HYD, San Isidro, Buenos Aires, Argentina \\ ${ }^{\mathrm{b}}$ Facultad de Ciencias Naturales y Museo, Universidad Nacional de La Plata, Paseo del Bosque s/n, La Plata, B1900FWA, Argentina \\ ${ }^{\mathrm{c}}$ Instituto de Investigaciones en Biodiversidad y Medioambiente, Universidad Nacional del COMAHUE, CONICET, Quintral 1250, San Carlos de Bariloche \\ R8400FRF, Argentina \\ d Centro de Investigaciones Geológicas, Universidad Nacional de La Plata, CONICET, Calle 113 y calle 64 s/n, B1900TAC, La Plata, Argentina \\ e CEBBAD, Fundación de Historia Natural "Félix de Azara”, Universidad Maimónides, 1405, Buenos Aires, Argentina
}

\section{A R T I C L E I N F O}

\section{Article history:}

Received 4 May 2016

Received in revised form

11 December 2016

Accepted in revised form 17 December 2016

Available online 18 December 2016

\section{Keywords:}

Anatomy

Argentina

Cycadales

Fossils

Patagonia

South America

Systematics

\begin{abstract}
A B S T R A C T
The cycads are remnants of a flora that dominated the terrestrial ecosystems across the Mesozoic Era. The stem record of fossil cycads is scanty, with seventeen genera described around the world. From them, eight come from Argentina (Triassic to Paleogene strata), and actually six from the Cretaceous of Patagonia. In this research, we present a new fossil trunk of cycad from Upper Cretaceous beds of Patagonia. The good preservation of the permineralized stem allows to make detailed descriptions and comparisons and, accordingly, support the erection of a new taxon, Zamuneria amyla gen. et sp. nov. This new taxon possesses characters that fit with the Encephalarteae (e.g., columnar stem with persistent leaf bases and cataphylls, a wide pith, medullary vascular bundles, mucilage canals and idioblasts, a polyxylic vascular cylinder). Some features present in Zamuneria are discussed, such as the great development of parenchyma tissues with a marked amount of specialized cells (idioblasts), probably related with some protective function. Furthermore, the presence of cycads during the deposition of the Mata Amarilla Formation allows inferring climatic conditions, as well as a greater diversity of Encephalarteae in South America reinforces the endemic conditions for this group for the Cretaceous of southern continents.
\end{abstract}

(c) 2016 Elsevier Ltd. All rights reserved.

\section{Introduction}

The Cycadales are the most antique and basal of living seedbearing plants. Actually, the living cycads are just small remnants of a surprisingly diverse lineage of seed plants, with an origin during the Permian (Mamay, 1969; Zhu and Du, 1981; Du and Zhu, 1982; Gao and Thomas, 1989).

Extant cycads grow in tropical and subtropical areas, between c. $30^{\circ} \mathrm{N}$ and $35^{\circ} \mathrm{S}$ (Norstog and Nicholls, 1997; Hill et al., 2004). The Order Cycadales bears today 331 living species grouped in 10 genera: Bowenia J.D. Hook, Ceratozamia Brongniart, Cycas L., Dioon Lindley, Encephalartos J.G.C. Lehmann, Lepidozamia E. Regel, Macrozamia Miquel, Microcycas (Miquel) de Candolle, Stangeria T.

\footnotetext{
* Corresponding author. Instituto de Botánica Darwinion (ANCEFN - CONICET) Labardén 200, CC22, B1642HYD, San Isidro, Buenos Aires, Argentina.

E-mail addresses: gesaghi@gmail.com (L.C.A. Martínez), ari_iglesias@yahoo.com. ar (A. Iglesias), aartabe@museo.fcnym.unlp.edu.ar (A.E. Artabe), augustovarela@cig. museo.unlp.edu.ar (A.N. Varela).
}

Moore y Zamia L. (Stevenson, 1990, 1992; Hill et al., 2003; Hill et al., 2004; Osborne et al., 2012).

At present, the genus with the most species is Cycas (107 spp.), followed by Zamia (71 spp.), Encephalartos (65 spp.), Macrozamia (41 spp.), Ceratozamia (27 spp.) and Dioon (14 spp.); whereas other genera contain only a single (monotypic) or a few species (Osborne et al., 2012).

Fossil records indicate a more diversification and geographical distribution of Cycadales during all the Mesozoic, with a large number of genera and species. Although cycads survived the latest Cretaceous extinction, their fossil record shows a marked decline along the Cenozoic (Artabe and Stevenson, 1999; Brenner et al., 2003; Hill et al., 2003). Some authors suggest that extant genera of Cycadales have diversified recently since the Late Cretaceous to the Neogene (Nagalingum et al., 2011; Condamine et al., 2015); however, several major taxa and extant families can be recognized in the fossil record (Artabe and Stevenson, 1999; Martínez and Artabe, 2014). 
The fossil record of cycads in Argentina is diverse, containing leaves, stems and reproductive structures. It is continuous across the Mesozoic, beginning in the Triassic, with a peak in the Cretaceous, to decline and even disappear in the late Paleogene (Artabe and Stevenson, 1999; Artabe et al., 2004, 2005; Martínez et al., 2012; Martínez and Artabe, 2014), following the global cooling event.

In this research, we describe a new taxon of Cycadales from the Mata Amarilla Formation (Middle Cenomanian). Its anatomical features, prompts a systematic position within or very close to Encephalarteae for the new taxon. Furthermore, the Patagonian specimen here described suggests warm climatic conditions during the deposition of the Mata Amarilla Formation.

\section{Geological setting}

The Mata Amarilla Formation shows the best exposures of the lower Upper Cretaceous deposits in the Austral Basin (Fig. 1). It overlies the Piedra Clavada Formation with a transitional contact, and is unconformably covered by the marine deposits of the La Anita Formation (Varela et al., 2012a).

Based on facies analysis, Varela et al. (2012b) divide the Mata Amarilla Formation into three sections: lower, middle and upper. The lower and upper sections of the Mata Amarilla Formation consist of fine-grained sediments with littoral palaeosols interbedded with shell beds interpreted as littoral marine, lagoon, and estuary palaeoenvironments (Varela et al., 2011, 2012b). In contrast, the middle section is characterized by conglomerates to coarse-grained sandstones with subordinate mudstones in the west; whereas towards the east, it consists of medium- to coarse-grained sandstones with subordinate mudstones interpreted as fluvial deposits with palaeosols development (Varela, 2015).

The new cycad stem comes from the contact between the lower and middle section of the Mata Amarilla Formation at Cerro Fortaleza locality (Fig. 2).

The time of deposition of the middle section of the Mata Amarilla Formation was $\mathrm{U}-\mathrm{Pb}$ dated by means of zircons collected from a tuff layer at $96.2 \pm 0.7 \mathrm{Ma}$, corresponding to the middle Cenomanian (Varela et al., 2012a).

The sedimentary palaeoenvironment of the deposit containing the new cycad stem has been interpreted as a high-sinuosity meandering fluvial system (Varela, 2015). The cycad stem fossiliferous level is represented by an important increase in the degree of amalgamation of fluvial channels interpreted as a forced regression heterogeneous surface located in the contact between the lower and middle sections of the Mata Amarilla Formation (Varela, 2015; Varela et al., 2015). Toward the north east of the basin, that surface is represented by a low-sinuosity meandering fluvial system with well-developed palaeosols containing in situ petrified forests, where large conifer fossil woods were described (Zamuner et al., 2004; Varela et al., 2015).

The Cerro Fortaleza locality provided abundant petrified trunks and woods within amalgamated sheet-like channel deposits (Fig. 1). Large conifer trunks (40-95 cm in diameter) are abundant at the same stratigraphic level (Varela et al., 2015).

Although with some degree of transportation, all known fossil trunks, including the cycad stem here studied, are interpreted as parautochthonous, lying close to the original living site (Varela et al., 2015). Sedimentological analyses indicate that palaeosols where the cycad grew, were moderate to well-drained (Varela et al., 2012b; Varela et al., 2015).

\section{Materials and methods}

The new fossil material comes from the uppermost part of the Lower Section of Mata Amarilla Formation (Austral Basin), in the Cerro Fortaleza locality (Fig. 1). The material was found associated with a petrified forest dominated by fallen Podocarpaceae trunks (Varela et al., 2015).

The fossil studied comprises a single permineralized cycad trunk fossilized with amorphous silica (opal), although a few thin cracks filled with micro-crystalline quartz are evident.

Thin sections were made using traditional techniques for wood anatomy; transverse (CS), radial (RS) and tangential (TS) sections

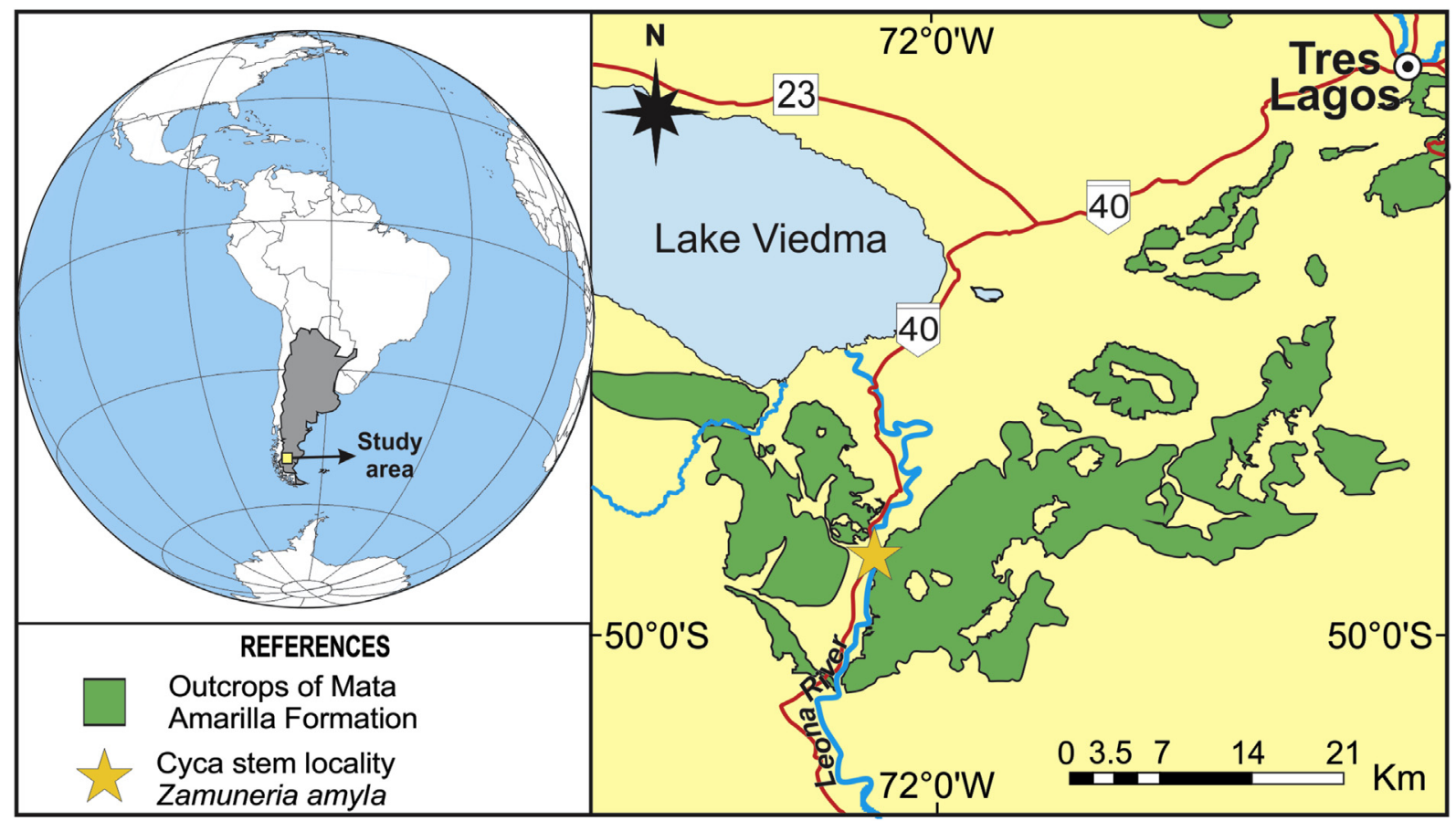

Fig. 1. Location map of the fossil site. 


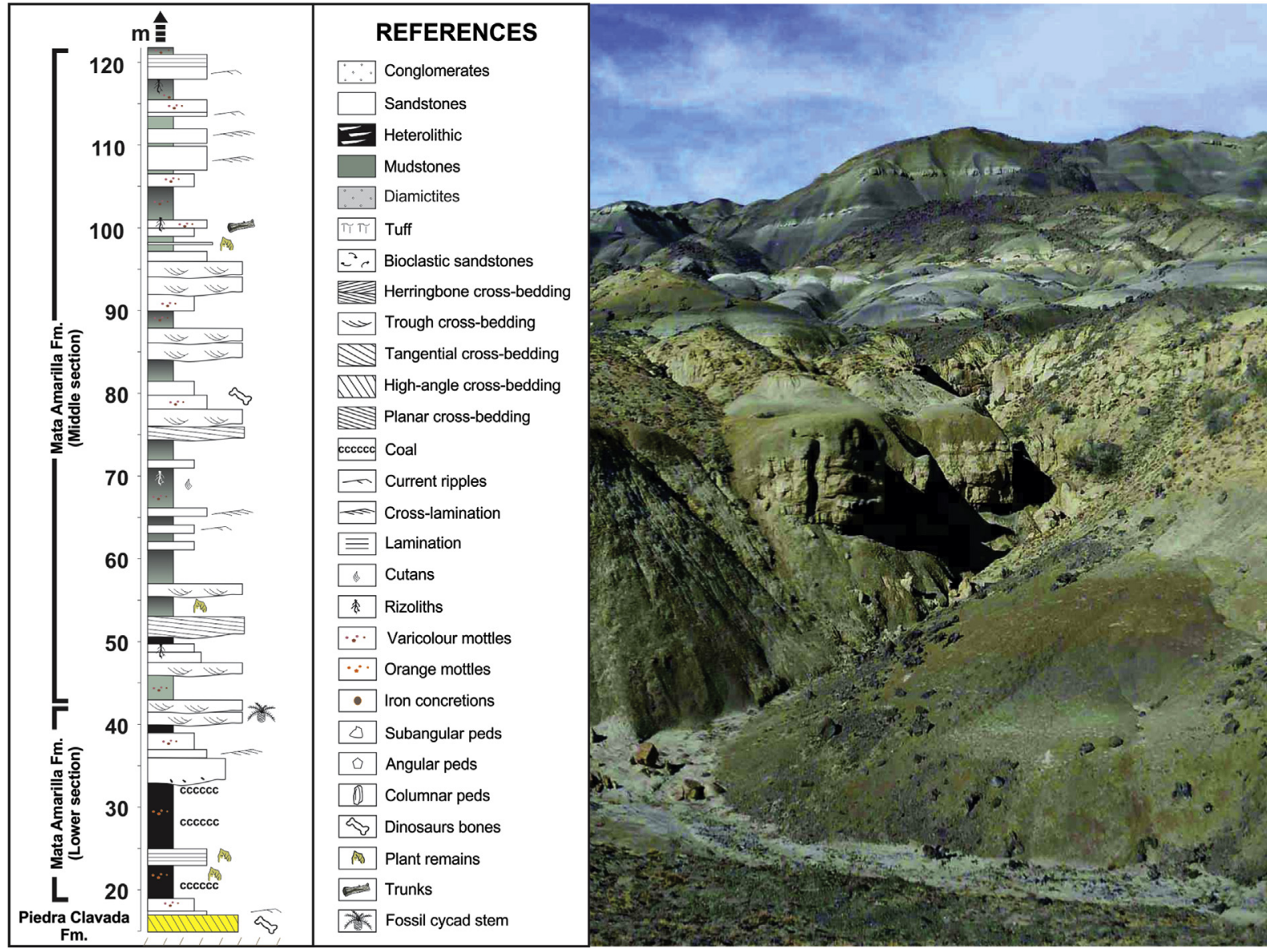

Fig. 2. Sedimentological section and general view of Cerro Fortaleza locality, Santa Cruz Province, Argentina.

were made to study wood anatomy. In addition, the fossil was examined with JEOL JSM 6360 LV scanning electron microscopy (SEM); the fossil stem was fractured and adhered to aluminium stubs using nail polish, and coated with a gold layer. The measurements are based on at least 25 measurements; the numbers in parentheses indicate the minimum and maximum values.

The fossil wood and thin sections are deposited in the Palaeontological Collection of Museo Padre Molina from Santa Cruz Province (MPM-PB), and in the Collection of the Paleobotany Division of Museo de La Plata (LPPB), La Plata, Argentina.

In order to improve description and make more comparisons, original pieces and thin sections of other fossil taxa (e.g. Michelilloa, Vladiloxylon, Neochamberlainia, Brunoa, Worsdellia, Wintucycas, Bororoa and Menucoa) were revised.

\subsection{Systematic palaeobotany}

The extant cycads form a monophyletic group (Stevenson, 1990; Soltis et al., 2002). However, the classification of cycads presents numerous uncertainties and, at present, the molecular phylogenies are not consistent with the morphological analysis (Hill et al., 2003; Zgurski et al., 2008). Several cycad clades are strongly supported by the molecular data: including one that defines a sister group relationship between Cycas and all other cycads, a Microcycas-Zamia clade, and the Encephalarteae (Macrozamia (Encephalartos, Lepidozamia) (Zgurski et al., 2008). However, for practical purposes, we follow here the classic systematic arrangement proposed by Stevenson (1992) based only on anatomical and morphological characters.
Cycadales Dumortier

Zamiineae Stevenson

Family Zamiaceae Reichenbach

Subfamily Encephalartoideae Stevenson

Tribe Encephalarteae Miquel

Genus Zamuneria Martínez, Iglesias \& Artabe, gen. nov.

Type species: Zamuneria amyla Martínez, Iglesias \& Artabe, gen. et sp. nov.

Figs. 3-11

Holotype. MPM-Pb-17527, Isotype: LPPB-14021, pmLPPB-1938 to pmLPPB-1949.

Locality. Cerro Fortaleza locality $\left(49^{\circ} 56^{\prime} 40^{\prime \prime} \mathrm{S}, 72^{\circ} 03^{\prime} 50^{\prime \prime} \mathrm{W}\right)$, Santa Cruz Province, Argentina (Fig. 1).

Stratigraphic horizon. Mata Amarilla Formation, lower Upper Cretaceous (middle Cenomanian).

Generic diagnosis. Columnar, polyxylic stem, covered by persistent rhomboidal leaf bases and cataphylls. Parenchymatous central pith with mucilage canals, idioblasts and medullary vascular bundles. Cylindrical vascular system centrifugal, with many rings of manoxylic secondary xylem and phloem, containing primary and secondary rays. Primary rays with leaf traces and a mucilage canal associated. Parenchymatous cortex with mucilage canals, idioblasts and girdling leaf traces in the cortex.

Etymology. The genus honours the late Dr. Alba B. Zamuner, an Argentinian palaeobotanist who passed away in 2012, and who made significant contributions to our knowledge of fossil floras from Argentina. She was one of the leaders of the expedition in which this fossil was discovered. 

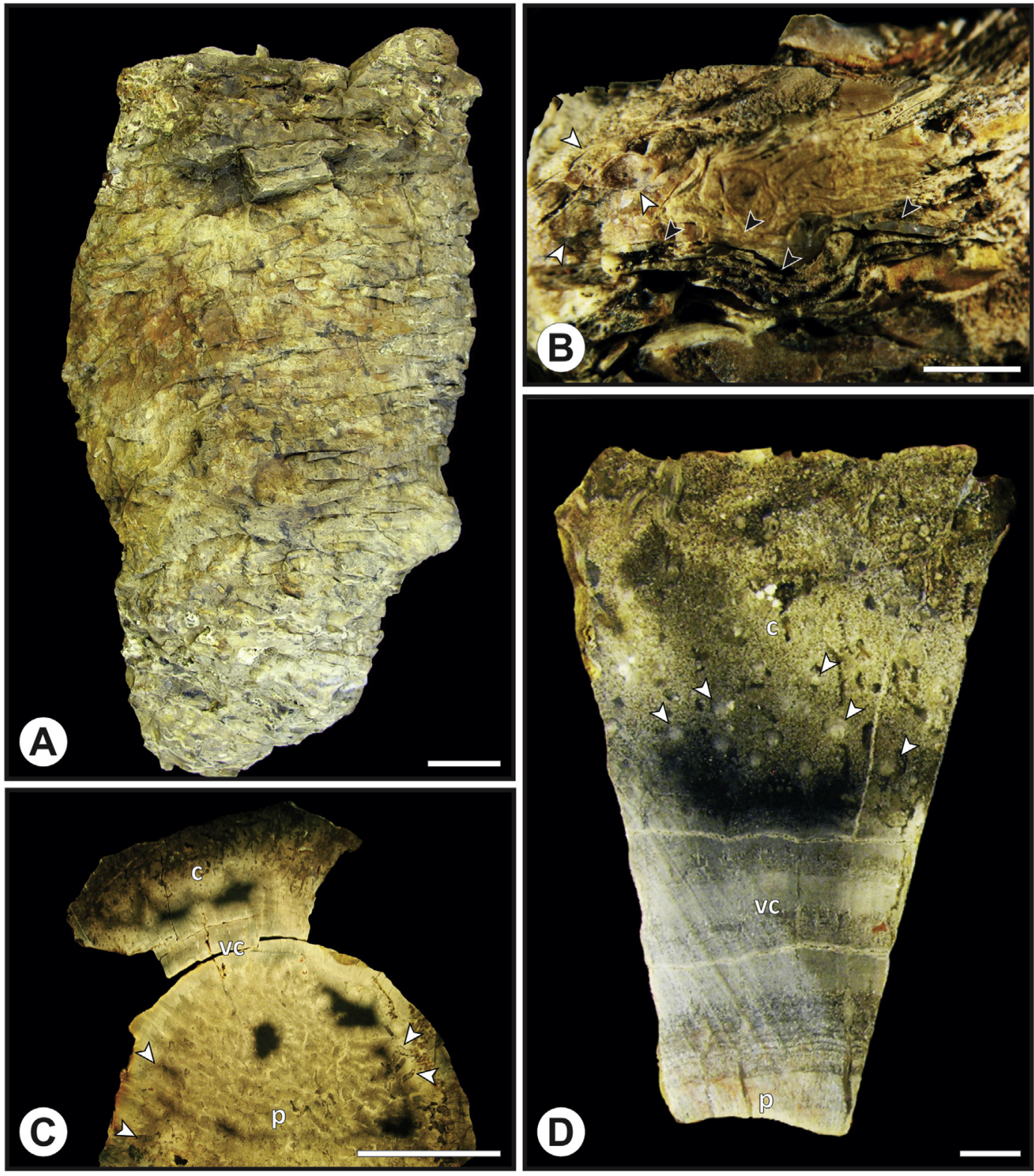

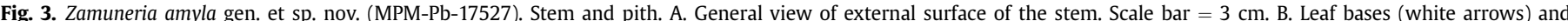

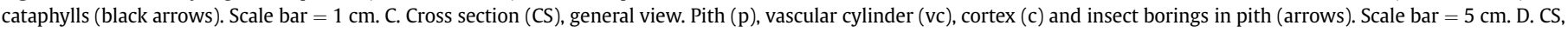
Detail of pith (p), vascular cylinder (vc), cortex (c) and cortical bundles (arrows). Scale bar $=1 \mathrm{~cm}$.

\section{Zamuneria amyla Martínez, Iglesias \& Artabe, gen. et sp. nov.}

Species diagnosis. A columnar and polyxylic stem, covered by persistent rhomboidal leaf bases and cataphylls. A wide and parenchymatous central pith with mucilage canals, idioblasts and medullary vascular bundles. The vascular system comprises a medullary vascular system, and a cylindrical vascular system. The medullary vascular system is composed of many scattered medullary vascular bundles. The cylindrical vascular system has concentric rings of centrifugal secondary xylem and phloem (polyxylic) toward the cortex, separated by wide multiseriate parenchymatic rays (primary rays). Primary rays with vascular bundles and mucilage canals. Tracheids of secondary xylem with uni- to triseriate contiguous and alternate bordered pits in walls. Manoxylic secondary xylem and phloem with homocellular multiseriate rays, with one to three cells wide (secondary rays). Cortex composed of fundamental parenchyma cells and idioblasts, mucilage canals and girdling leaf traces.

Etymology. The name of species is derived from Latin noun amylum (starch), by the abundance of parenchyma cells with lots of starch grains in the fossil stem.

\section{Description}

The stem is columnar (pachycaulous) and incomplete, with a diameter of $0.13 \mathrm{~m}$ and $0.31 \mathrm{~m}$ of length (Fig. 3A). The stem has an armour of persistent leaf bases and cataphylls. However, leaf bases and cataphylls are preserved only in a small section of the fossil (Fig. 3B).

In cross-section, the stem can be divided into four regions: the pith, cylindrical vascular system, the cortex (Fig. 3B), and persistent leaf bases (Fig. 3C). 

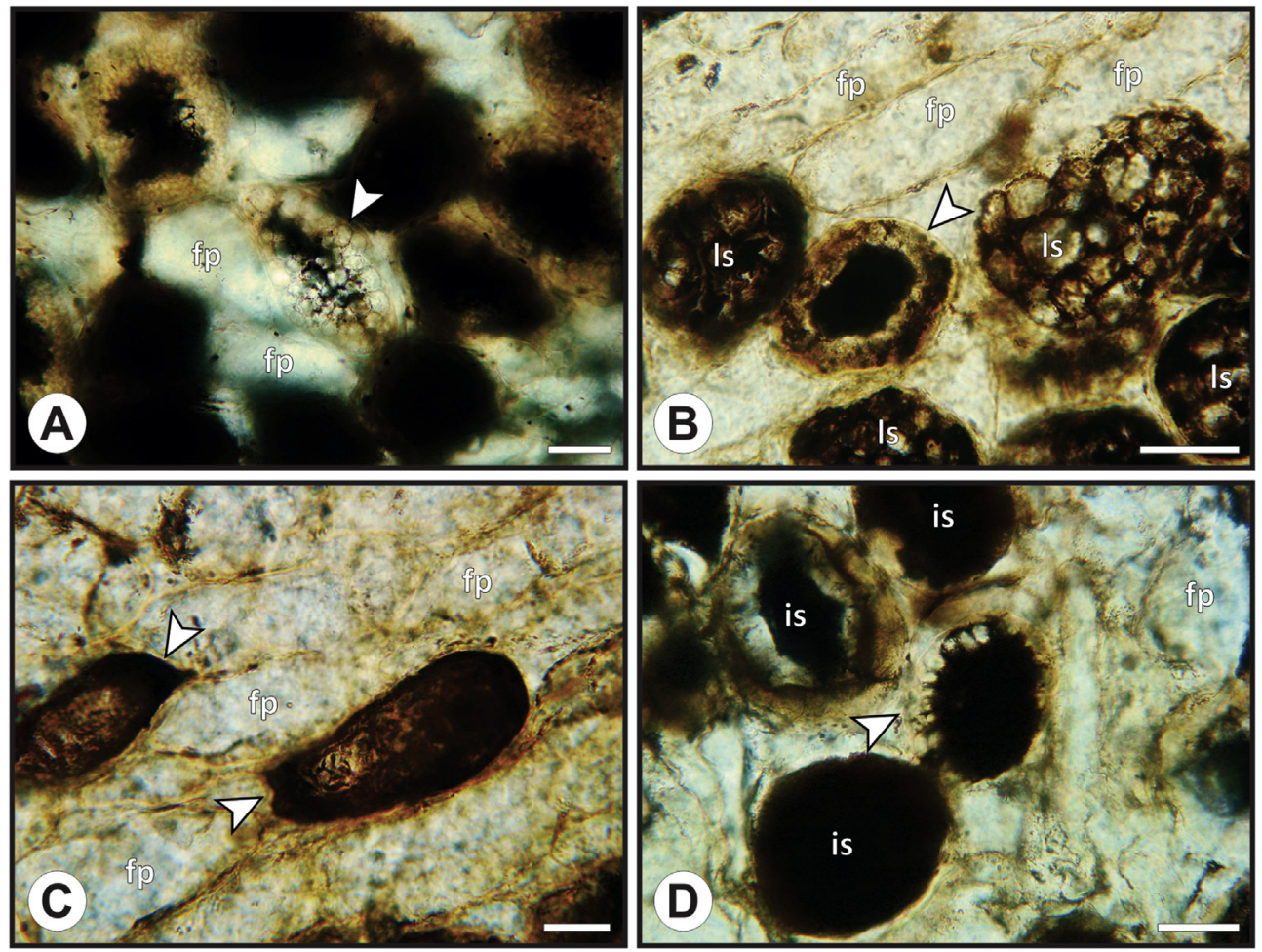

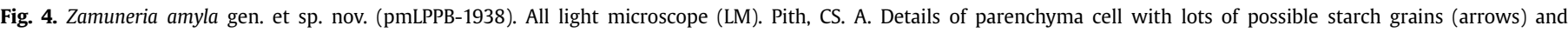

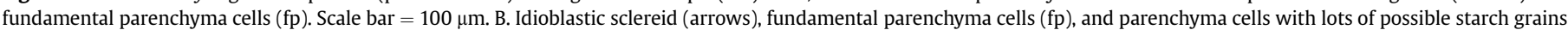

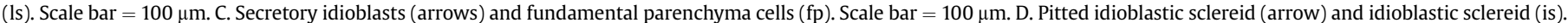
Scale bar $=100 \mu \mathrm{m}$.

\subsection{Pith}

In cross section, the pith is circular to oval in outline, with a diameter of $0.10 \mathrm{~m}$, occupying the largest portion of the stem (Fig. 3C, D). The pith is composed of parenchymatous cells, idioblasts, numerous medullary vascular bundles (medullary vascular system), and mucilage canals (Fig. 3C, D). The fundamental parenchyma cells are thin-walled, and isodiametric, with an average diameter of $70 \mu \mathrm{m}(50-110 \mu \mathrm{m})$. Usually, the parenchyma cells have circular to oval simple pits, and most of these cells contain lots of possible starch grains (Fig. 4A, B). Among the parenchyma cells, there are many idioblasts characterized by the presence of lignified thick secondary cell walls, and can be classified (sensu Vovides, 1991 ) into: secretory idioblasts, idioblastic sclereids and pitted idioblastic sclereids (Fig. 4B-D).

The medullary vascular system consists of secondary vascular bundles that are randomly arranged in the pith. The bundles are numerous, with a mean diameter of $1205 \mu \mathrm{m}(810-2160 \mu \mathrm{m})$. They are collateral, composed of xylem and phloem, commonly accompanied by a mucilage canal (Fig. 5A, B). In longitudinal section, the vascular bundles are large, irregular in course, and sometimes branching. The medullary bundles are not related to reproductive structures, and do not form regularly arranged rings, for these reasons they are not related to cone domes. The cone domes are a sequence of dome-like vascular bundle patterns in a longitudinal section of the cycad stems with terminal strobili (Chamberlain, 1911; Norstog and Nicholls, 1997).

In cross section, the mucilage canals are circular of ovoid in outline, with a diameter of $170 \mu \mathrm{m}(80-270 \mu \mathrm{m})$. They are composed by secretory cells to form an internal lumen to store mucilage (Fig. 5A, B). The epithelial cells lining the mucilage canals have the nuclei preserved (Fig. 5C). Some transfusion cells are occasionally observed adjacent to the vascular bundles on the outer part of pith, close to vascular cylinder (Fig. 5D, E).

\subsection{Cylindrical vascular system}

The cylindrical vascular system has a centrifugal growth pattern, and consists of many sympodia of endarch primary xylem in a circumferential arrangement (Fig. 6A, B). The primary xylem is followed by alternative rings of secondary xylem and phloem (polyxylic), and secondary rays, separated by wide multiseriate parenchymatic rays (primary rays) (Fig. 6C). In cross section, the primary xylem has oval to square tracheids; with a mean radial diameter of $14 \mu \mathrm{m}(6-35 \mu \mathrm{m})$, and a tangential diameter of $14 \mu \mathrm{m}$ (6-19 $\mu \mathrm{m})$ (Fig. 6A, B).

The secondary vascular cylinder is polyxylic, composed of three successive rings of xylem, cambium and phloem; and segmented by primary rays that connect the pith with the cortex (Fig. 6C). The secondary xylem has rectangular to square tracheids with a mean radial diameter of $23 \mu \mathrm{m}(14-35 \mu \mathrm{m})$ and a tangential diameter of $21 \mu \mathrm{m}(13-29 \mu \mathrm{m})$ (Fig. 6D). The vascular cambium is located between secondary xylem and phloem, and comprises a series of two to four rectangular cells with thin walls (Fig. 6C, E). The phloem possesses sieve, parenchyma and sclerenchymatous cells (Fig. 7A). The sieve and parenchyma cells (thin-walled cells) are positioned among fibre bands (thick-walled cells) (Fig. 7A, B).

Each ring of centrifugal secondary xylem and phloem is composed of many vascular segments separated by wide parenchymatous rays (primary rays); between them, there are many thin rays (secondary rays) (Fig. 6D). Parenchyma cells essentially constitute the primary and secondary rays (Fig. 7C). Pitted idioblastic sclereids and secretory idioblasts are commonly present in the rays (Fig. $7 \mathrm{C}, \mathrm{D}$ ). 

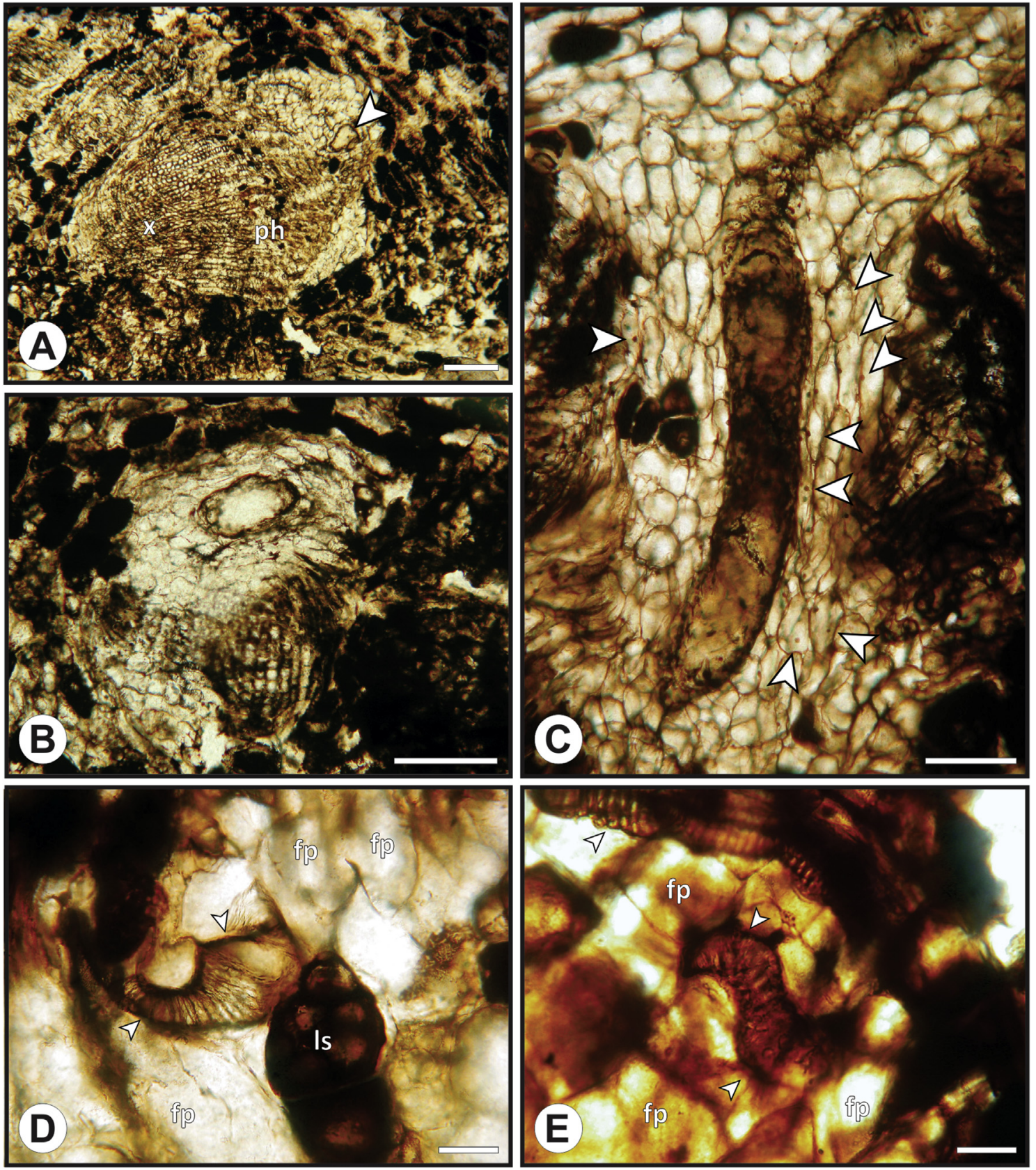

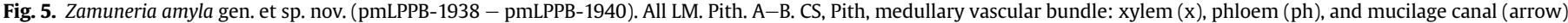

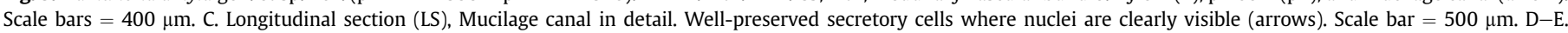
Transfusion cells (arrows), fundamental parenchyma cells (fp), and parenchyma cells with lots of possible starch grains (ls). Scale bars $=100 \mu \mathrm{m}$.

In radial section, the secondary xylem has tracheids with araucarioid pitting. The pits are uni- to tri-seriate and bordered, flattened to hexagonal in outline, with a contiguous and alternate disposition (Figs. 7E, 8A, B). The pits have a horizontal diameter of $9 \mu \mathrm{m}(6-12 \mu \mathrm{m})$ and a vertical diameter of $8 \mu \mathrm{m}(5-12 \mu \mathrm{m})$ (Fig. 8A, B). The apertures are circular to oval in outline. The crossfields have a mean of $8(6-10)$ oculipores of the araucarioid type (Fig. 7F).

In tangential section, the secondary rays are fusiform composed of parenchyma cells, and few secretory idioblasts. There is a mean of 25 (9-35) secondary rays between the two primary rays. The high number of secondary rays (parenchyma) makes the wood manoxylic.
The primary rays are heterocellular, composed of parenchyma cells, idioblasts, and secretory cells (mucilage canals). The primary rays have a mean diameter of $1130 \mu \mathrm{m}(720-1440 \mu \mathrm{m})$, and $5140 \mu \mathrm{m}(4350-5710 \mu \mathrm{m})$ in height. Inside the primary rays there is a leaf trace (vascular elements) with a mucilage canal associated (Fig. 9A, B). The secondary rays are 1- to 3-seriate, with a mean diameter of $101 \mu \mathrm{m}(35-168 \mu \mathrm{m})$ and a height of $1705 \mu \mathrm{m}$ $(71-470 \mu \mathrm{m})$ (Fig. 9C).

The ray cells are oval to rectangular in outline, with a diameter of $38 \mu \mathrm{m}(19-80 \mu \mathrm{m})$ and a height of $40 \mu \mathrm{m}(20-70 \mu \mathrm{m})$ (Fig. 9C).The parenchyma cells are commonly circular, elliptic, upright or occasionally procumbent. The idioblasts are generally circular to oval, however some of them are fusiform to elongate. 

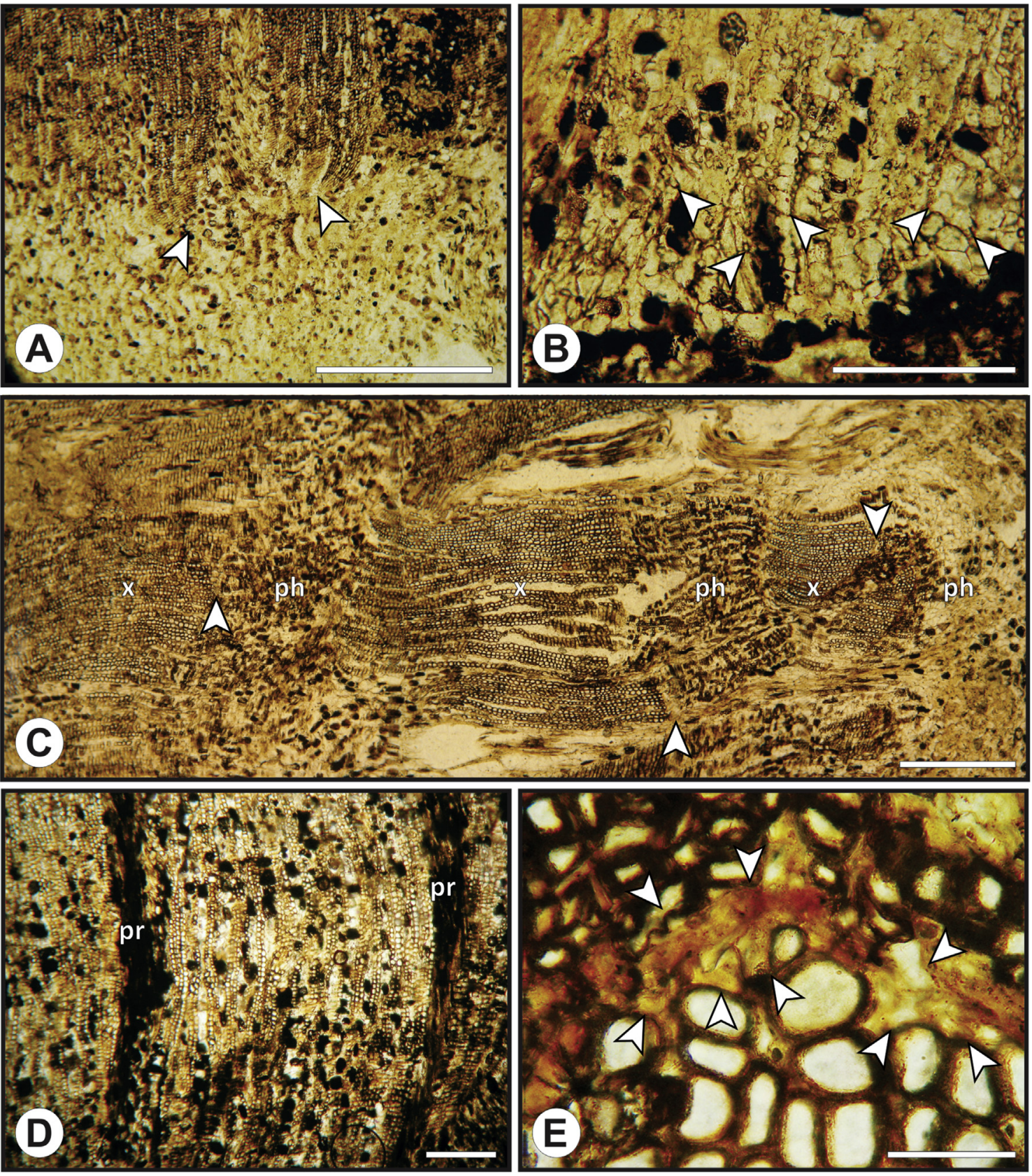

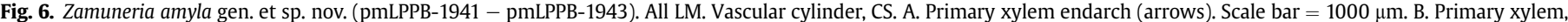

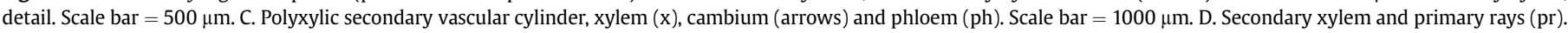
Scale bar $=500 \mu \mathrm{m}$. E. Detail of cambium cells (arrows). Scale bar $=50 \mu \mathrm{m}$.

\subsection{Cortex}

In cross section, the cortex is composed of parenchyma cells, idioblasts, mucilage canals and leaf traces. The features and dimensions of parenchyma cells and idioblasts are similar to those present in the pith (Fig. 10A-D). The parenchyma cells are isodiametric with an average diameter of $70 \mu \mathrm{m}(50-12 \mu \mathrm{m})$. The leaf traces comprise many collateral vascular bundles and girdling traces scattered in the cortex (Fig.11A-B). They are commonly associated with a mucilage canal. The mucilage canals are scattered among the parenchyma cells and more abundant than in the pith; their average diameter is $550 \mu \mathrm{m}(360-930 \mu \mathrm{m})$ (Fig.11A-B).

\subsection{Leaf bases}

Most of the outer part of the stem is not preserved; however, in a small area it is possible to observe helical persistent leaf bases and cataphylls (Fig. 3B). The leaf bases are rhomboidal and small, with a $1.2 \mathrm{~cm}(0.8-1.4 \mathrm{~cm})$ wide and $0.5 \mathrm{~cm}(0.3-0.7 \mathrm{~cm})$ high.

\subsection{Animal activity}

The stem bears tunnels and galleries bored by animal activity into their different tissues. The tunnels were bored into the cortex, vascular tissue (phloem) or between the vascular tissue and the 

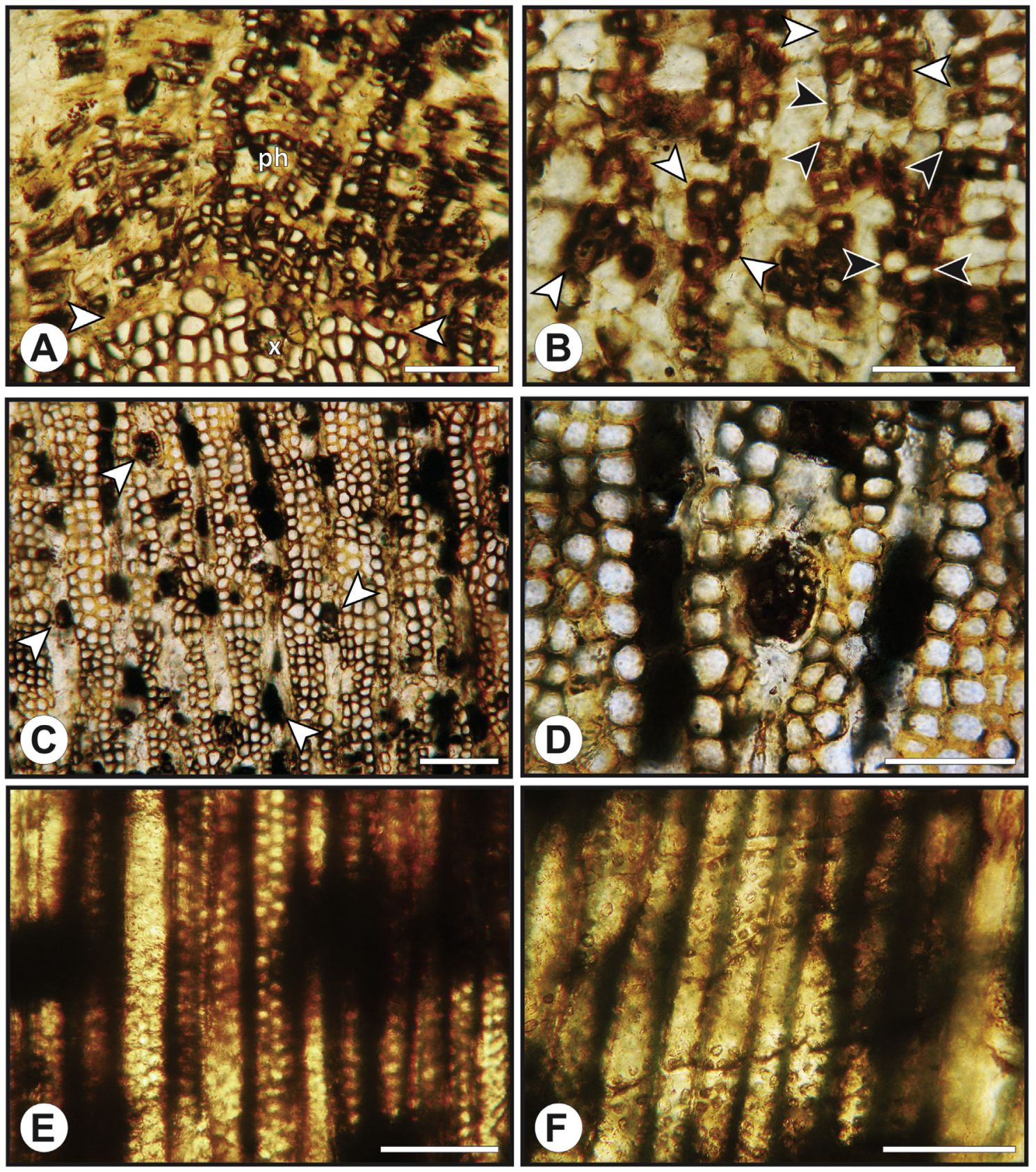

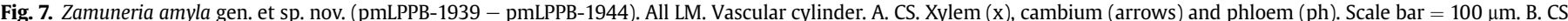

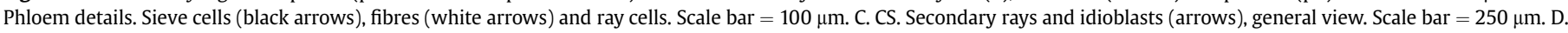

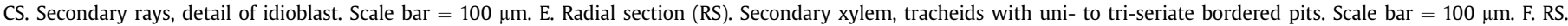
Araucariod cross fields. Scale bar $=100 \mu \mathrm{m}$.

pith. The galleries are circular, oval to irregular in outline, and generally filled with abundant frass (Fig. 3C).

\section{Discussion}

The features described for the fossil stem are characteristic of the Cycadales, such as pachycaulous stem, an armour of leaf bases, parenchymatous cortex with girdling traces, centrifugal polyxylic vascular cylinder, and a large parenchymatous pith with vascular bundles and mucilage canals (Greguss, 1968; Stevenson, 1990, 1992; Artabe and Stevenson, 1999). In order to classify and assign the fossil trunk here described into a taxonomic category of the Order Cycadales, it was compared with extant and fossil cycads. The characters of the studied material allow us to assign it to a new genus Zamuneria. The new taxon has numerous characters that are argued below, and displayed in Tables 1 and 2 .

\subsection{Comparisons}

\subsubsection{Comparisons with extant cycad stems}

Zamuneria has a columnar stem, arborescent habit, persistent armour of leaf bases and cataphylls, like some living cycad genera: Cycas, Dioon, Encephalartos, Lepidozamia and Macrozamia (Norstog and Nicholls, 1997; Artabe et al., 2005). On the other hand, Microcycas, Ceratozamia and Zamia have smooth trunks (Norstog and Nicholls, 1997; Artabe et al., 2005); whereas Bowenia and 

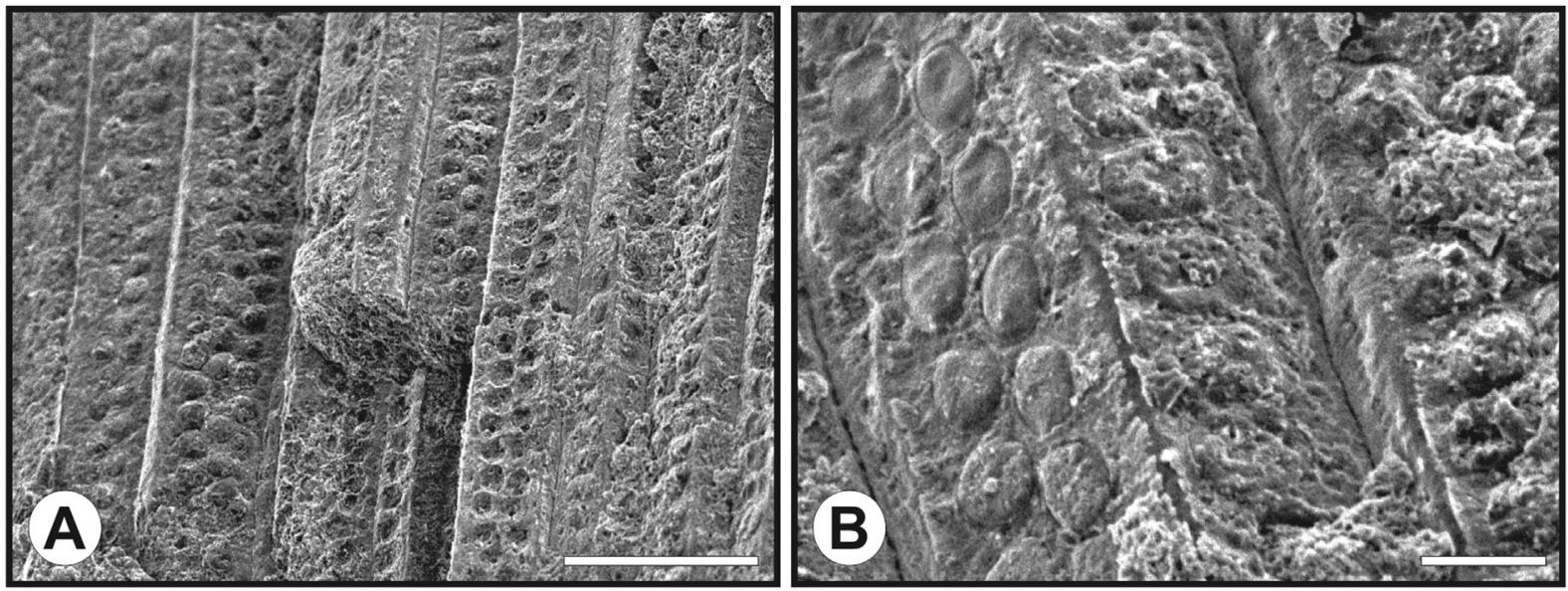

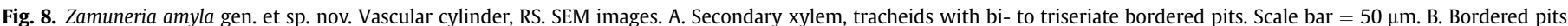
(detail). Scale bar $=10 \mu \mathrm{m}$
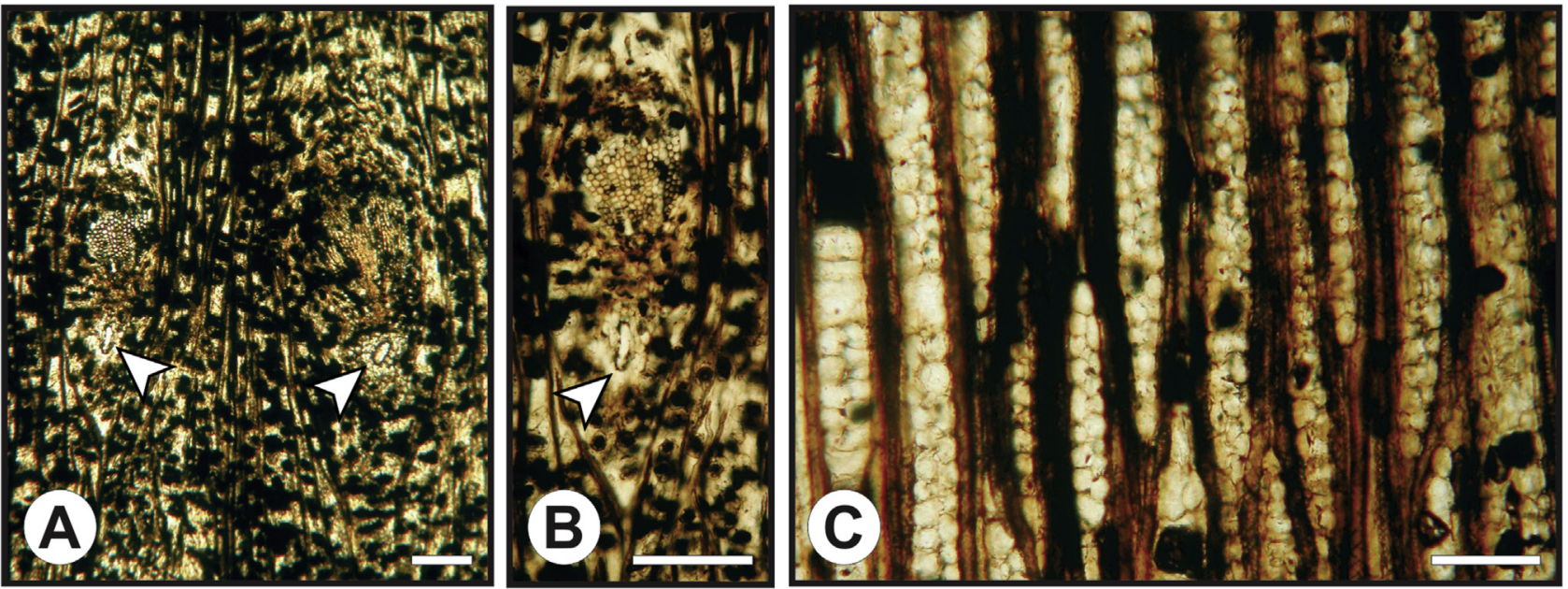

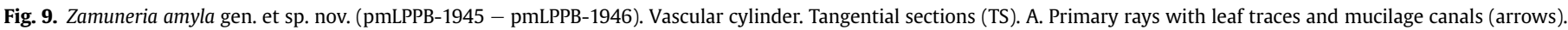
Scale bar $=1000 \mu \mathrm{m}$. B. TS. Primary rays (detail). Scale bar $=500 \mu \mathrm{m}$. C, TS. Secondary rays. Scale bar $=250 \mu \mathrm{m}$.

Stangeria have naked subterranean stems (Norstog and Nicholls, 1997). The presence of cone domes and lack of a medullary vascular system distinguish Cycas, Dioon, Stangeria, Bowenia, Ceratozamia, Microcycas and Zamia from Zamuneria (Worsdell, 1896, 1906; Greguss, 1968; Stevenson, 1992; Artabe et al., 2005).

The centrifugal polyxyly, manoxyly and medullary vascular system are characters present in Zamuneria, and in Encephalartos, Macrozamia and Lepidozamia (Worsdell, 1896, 1906; Artabe et al., 2005).

Although, the presence of a centripetal vascular system is rare or sporadic in extant forms, it is treated as a regular character in systematic studies, and occurs on the stem base of some species of Macrozamia, Lepidozamia, Encephalartos, and Cycas (Worsdell, 1896, 1906). However, Zamuneria do not have any evidence of a centripetal vascular system.

Zamuneria shares the presence of the medullary vascular bundle system and the centrifugal polyxyly with Encephalartos, Lepidozamia, and Macrozamia. (Stevenson, 1992). It is interesting to note that the medullary vascular system is a synapomorphy of Tribe Encephalarteae (Stevenson, 1990, 1992), allowing the inclusion of Zamuneria among members of this Tribe. However, Zamuneria differs from the living members of Encephalarteae in the absence of cortical steles and centripetal vascular system. The comparisons among Zamuneria and living cycads are summarized in Table 1.

\subsubsection{Comparisons with fossil cycad stems}

The fossil cycad stems are scarce, with 17 fossil genera described from Triassic to Paleogene, of which eight are from Argentina (Martínez et al., 2012; Zhang et al., 2012).

Five cycad fossil stems were described from the Triassic: Michelilloa Archangelsky et Brett (1963) from Argentina; Vladiloxylon Lutz, Crisafulli, et Herbst (2003) from Chile; Lyssoxylon Daugherty (Gould, 1971) and Charmorgia Ash (1985) from the United States of America; and Antarcticycas Smoot, Taylor et Delevoryas (1985) emend. Hermsen, Taylor, Taylor et Stevenson (2006) of Antarctica. The Jurassic taxa are: Lioxylon Zhang, Wang, Saiki, Li et Zheng (2006) and Sinocycadoxylon Zhang, Yang, Fu, Zheng et Wang (2012) from China, and Fascisvarioxylon Jain (1962) from the Upper Jurassic-Lower Cretaceous of India. Among the Cretaceous forms, there are Sanchucycas Nishida, Nishida et Tanaka (1991) from Japan, Centricycas Cantrill (2000) from Antarctica, and there are four genera from Argentina; Worsdellia Artabe, Zamuner et Stevenson (2004), Brunoa Artabe, Zamuner et Stevenson (2004), Neochamberlainia Artabe, Zamuner et Stevenson (2005, 2010) and Wintucycas Martínez, Artabe et Bodnar (2012). Finally, Bororoa Petriella $(1972,1978)$ and Menucoa Petriella (1969) are known from the Paleogene of Argentina.

All Triassic taxa described have a monoxylic stem with a centrifugal vascular system such Michelilloa, Vladiloxylon, Lyssoxylon, 

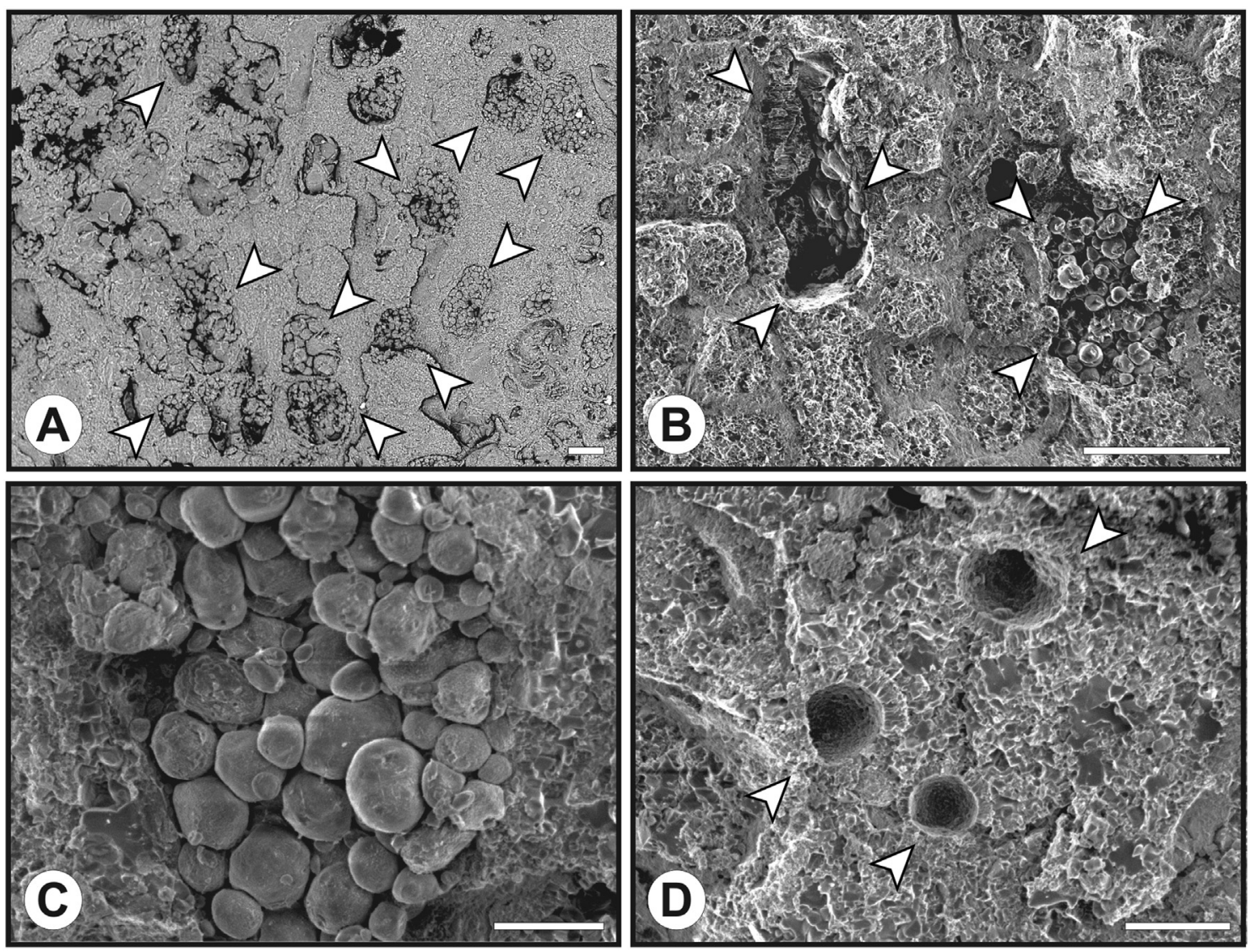

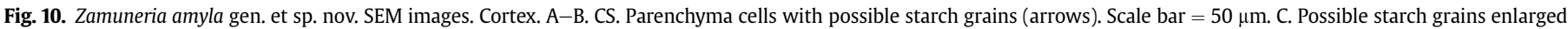
Scale bar $=10 \mu \mathrm{m}$. D. Idioblasts with thick secondary cell walls (arrows). Scale bar $=10 \mu \mathrm{m}$.
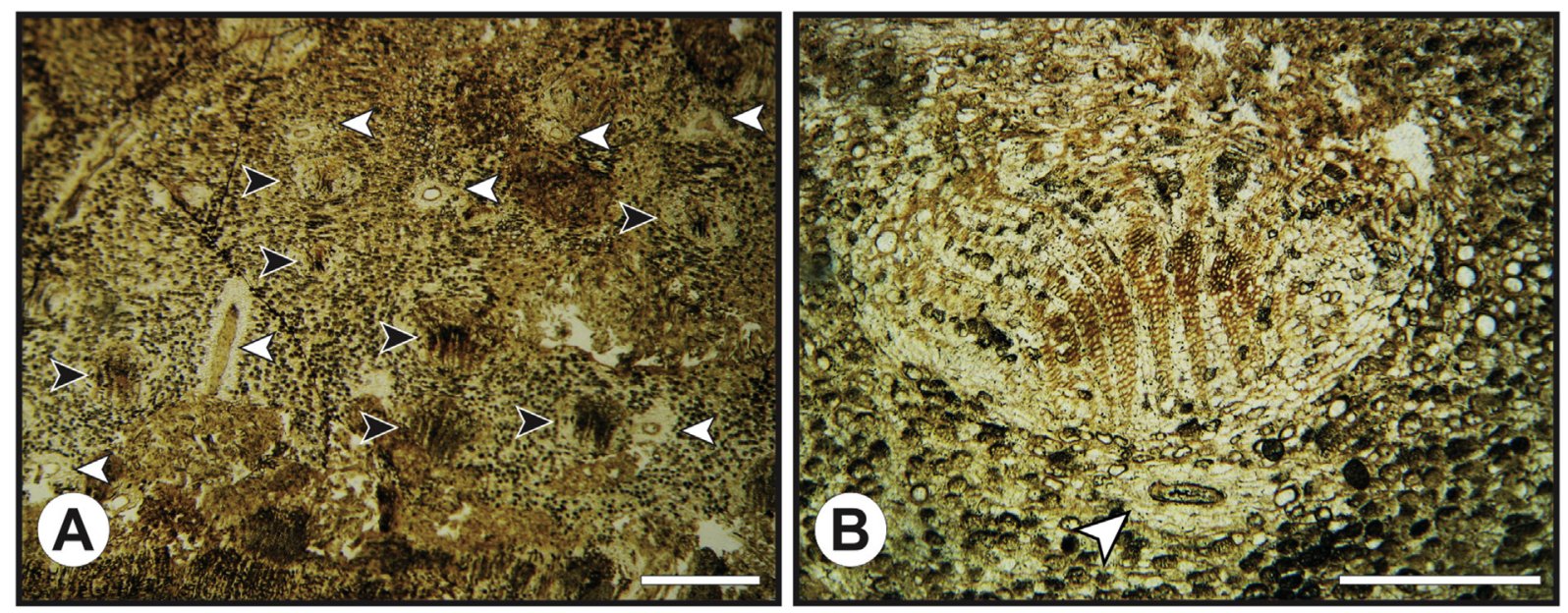

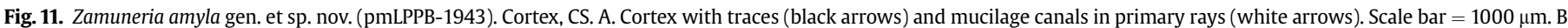
Detail of a vascular trace and mucilage canal (arrow). Scale bar $=500 \mu \mathrm{m}$.

Charmorgia and Antarcticycas, features that essentially distinguish Zamuneria from those genera.

The Jurassic genera also have characters that easily segregate Zamuneria. Lioxylon and Sinocycadoxylon are distinguished by the possession of polyxylic stems with centripetal and centrifugal vascular systems, whereas Fascisvarioxylon has a monoxylic stem, cone domes and mucilage cavities.
The Cretaceous genera are numerous and diverse. Sanchucycas has mucilage cavities, and Centricycas possesses monoxylic stems, these features contrasts with those present in the fossil studied here. The remaining Cretaceous genera come from Patagonia and, in some way, they are closer to Zamuneria. On one hand, Brunoa has cone domes and mucilage cavities, features that clearly permit the distinction from Zamuneria. On the other hand, 
Table 1

Comparisons among Zamuneria and extant genera stems of Cycadales (characters shared by those of Zamuneria are in italics).

\begin{tabular}{|c|c|c|c|c|c|c|c|c|c|}
\hline & Mucilage & $\begin{array}{l}\text { Medullary } \\
\text { bundles }\end{array}$ & Centripetal polyxyly & $\begin{array}{l}\text { Cone } \\
\text { domes }\end{array}$ & $\begin{array}{l}\text { Secondary centrifugal } \\
\text { polyxyly }\end{array}$ & $\begin{array}{l}\text { Wood } \\
\text { parenchyma }\end{array}$ & $\begin{array}{l}\text { Cortical } \\
\text { steles }\end{array}$ & $\begin{array}{l}\text { Petiole bundle } \\
\text { pattern }\end{array}$ & $\begin{array}{l}\text { Cataphylls in } \\
\text { vegetative axes }\end{array}$ \\
\hline Cycas & Canals & Absent & $\begin{array}{l}\text { Random or } \\
\text { discontinuous cycles }\end{array}$ & Present & Present & Abundant & Present & Omega classic & Present \\
\hline Stangeria & Canals & Absent & Absent & Present & Absent & Abundant & Absent & Omega elaborate & Absent \\
\hline Bowenia & Canals & Absent & Absent & Present & Absent & Abundant & Present & Omega elaborate & Absent \\
\hline Dioon & Canals & Absent & Absent & Present & Absent & Scanty & Absent & Omega classic & Present \\
\hline Encephalartos & Canals & Present & $\begin{array}{l}\text { Random or } \\
\text { discontinuous cycles }\end{array}$ & Absent & Present & Abundant & Present & Omega elaborate & Present \\
\hline Macrozamia & Canals & Present & $\begin{array}{l}\text { Random or } \\
\text { discontinuous cycles }\end{array}$ & Absent & Present & Abundant & Present & Omega classic & Present \\
\hline Lepidozamia & Canals & Present & $\begin{array}{l}\text { Random or } \\
\text { discontinuous cycles }\end{array}$ & Absent & Present & Abundant & Present & Omega classic & Present \\
\hline Ceratozamia & Canals & Absent & Absent & Present & Absent & Abundant & Absent & Omega classic & Present \\
\hline Microcycas & Canals & Absent & Absent & Present & Absent & Abundant & Absent & Omega classic & Present \\
\hline Zamia & Canals & Absent & Absent & Present & Absent & Abundant & Absent & Omega classic & Present \\
\hline $\begin{array}{l}\text { ZAMUNERIA } \\
\text { nov. gen. }\end{array}$ & Canals & Present & Absent & Absent & Present & Abundant & Absent & $?$ & Present \\
\hline
\end{tabular}

Worsdellia, Neochamberlainia and Wintucycas have some characters in common from Zamuneria such as, wide pith, medullary vascular system, and polyxylic centrifugal vascular system. However they are distinguishable by the presence of the centripetal vascular system. Furthermore, Worsdellia and Neochamberlainia have cortical steles.

Two cycad stems, Bororoa and Menucoa, are described from the lower Cenozoic of Argentinean Patagonia. The genus Bororoa is distinguished from the new taxa by the presence of cone domes, and Menuсoa has a centripetal vascular system (Petriella, 1969, 1972; Artabe and Stevenson, 1999).

The comparisons among the extant and fossil cycads support the uniqueness of the specimen described here, allowing us to erect a new taxon of cycad: Zamuneria amyla gen et sp. nov. The comparison with Zamuneria and fossil cycad taxa appears in Table 2. Identification key to all known fossil cycad stems is provided in Table 3.

\subsection{Idioblasts: ecological and systematic significance}

Zamuneria amyla has well-developed parenchymatous tissues with a marked number of specialized idioblasts. According to Vovides (1991) and Vovides et al. (1993) the term "idioblast" may be applied to a different type of cell, from those parenchymatous ones with specialized contents like tannin or oil, to scelerenchymatous cells, idioblastic sclereids, or trichoblasts. The idioblasts can be classified into three major categories: secretory, tracheoid, and sclerenchymatous (Metcalfe and Chalk, 1979).

The presence of idioblasts in living Cycadales has been noted sometimes (Greguss, 1968). They are scattered throughout the stem, especially in the pith, phloem, rays, the cortex and the sporophyll tissues of the strobili.

The identity of the substances contained in the idioblasts, as well as their functions are not well known, but at least some are thought to have protective functions. According to Norstog and

Table 2

Comparisons among fossil genera stems of Cycadales (characters shared by those of Zamuneria are in italics)

\begin{tabular}{|c|c|c|c|c|c|c|c|c|c|}
\hline & Mucilage & $\begin{array}{l}\text { Medullary } \\
\text { bundles }\end{array}$ & Centripetal polyxyly & $\begin{array}{l}\text { Cone } \\
\text { domes }\end{array}$ & $\begin{array}{l}\text { Secondary centrifugal } \\
\text { polyxyly }\end{array}$ & $\begin{array}{l}\text { Cortical } \\
\text { steles }\end{array}$ & $\begin{array}{l}\text { Wood } \\
\text { parenchyma }\end{array}$ & $\begin{array}{l}\text { Petiole bundle } \\
\text { pattern }\end{array}$ & $\begin{array}{l}\text { Cataphylls in } \\
\text { vegetative axes }\end{array}$ \\
\hline Antarcticycas & $\begin{array}{l}\text { Cavities \& } \\
\text { Canals }\end{array}$ & Absent & Absent & Present & Absent & Absent & Abundant & Omega & Present \\
\hline Charmorgia & Canals & Present & Absent & Absent & Absent & Absent & Abundant & Omega & Present \\
\hline Lyssoxylon & Canals & Absent & Absent & Absent & Absent & Absent & Scanty & $?$ & Absent \\
\hline Michelilloa & Canals & Absent & Absent & Absent & Absent & Absent & Scanty & $?$ & $?$ \\
\hline Vladiloxylon & Canals & Absent & Absent & Absent & Absent & Absent & Abundant & $?$ & $?$ \\
\hline Fascisvarioxylon & Cavities & Absent & Continuous cycle & Present & Absent & Absent & Abundant & $?$ & Present \\
\hline Lioxylon & Cavities & Present & Continuous cycle & Absent & Absent & Absent & Abundant & $\begin{array}{l}\text { Omega } \\
\text { elaborate }\end{array}$ & Present \\
\hline Sinocycadoxylon & Canals & Present & Continuous cycle & Absent & Present & $?$ & Scanty & $?$ & $?$ \\
\hline Brunoa & Cavities & Absent & Absent & Present & Present & Absent & Scanty & $\begin{array}{l}\text { Omega } \\
\text { elaborate }\end{array}$ & Present \\
\hline Centricycas & Canals & Present & Absent & Absent & Absent & $?$ & Abundant & $?$ & $?$ \\
\hline Neochamberlainia & Canals & Present & $\begin{array}{l}\text { Random or } \\
\text { discontinuous cycles }\end{array}$ & Absent & Present & Present & Abundant & $?$ & Present \\
\hline Sanchucyas & Cavities & Absent & Absent & Absent & Present & $?$ & Scanty & $?$ & $?$ \\
\hline Wintucycas & Canals & Present & $\begin{array}{l}\text { Random or } \\
\text { discontinuous cycles }\end{array}$ & Absent & Present & Absent & Abundant & $\begin{array}{l}\text { Omega } \\
\text { elaborate }\end{array}$ & Absent \\
\hline Worsdellia & Canals & Present & $\begin{array}{l}\text { Random or } \\
\text { discontinuous cycles }\end{array}$ & Absent & Present & Present & Abundant & $?$ & Present \\
\hline $\begin{array}{l}\text { ZAMUNERIA nov. } \\
\text { gen. }\end{array}$ & Canals & Present & Absent & Absent & Present & Absent & Abundant & $?$ & Present \\
\hline Bororoa & Canals & Absent & Absent & Present & Present & Absent & Abundant & $\begin{array}{l}\text { Omega } \\
\text { elaborate }\end{array}$ & Present \\
\hline меписоа & Canals & Present & $\begin{array}{l}\text { Random or } \\
\text { discontinuous cycles }\end{array}$ & Absent & Present & Absent & Abundant & $\begin{array}{l}\text { Omega } \\
\text { elaborate }\end{array}$ & Present \\
\hline
\end{tabular}


Table 3

Taxonomical key for fossil cycadalean stems.

\begin{tabular}{|c|c|c|}
\hline 1.1. & Monoxilic stems & 2 \\
\hline 1.2. & Polyxylic stems & 7 \\
\hline 2.1 . & Medullary bundles absent & 3 \\
\hline 2.2 & Medullary bundles present & 6 \\
\hline 3.1 & Growth rings present & 4 \\
\hline 3.2 & Growth rings absent & 5 \\
\hline 4.1 & Small medulla & $\begin{array}{l}\text { Vladiloxylon Lutz, Crisafulli } \\
\text { et Herbst }\end{array}$ \\
\hline 4.2 & Wide medulla & Lyssoxylon Gould \\
\hline 5.1 & With canals and cavities & $\begin{array}{l}\text { Antarcticycas Smoot, } \\
\text { Taylor et Delevoryas } \\
\text { emend. Hermsen et al. }\end{array}$ \\
\hline 5.2 & With canals & $\begin{array}{l}\text { Michelilloa Archangelsky et } \\
\text { Brett }\end{array}$ \\
\hline 6.1 & Mucilage canals present & Charmorgia Ash \\
\hline 6.2 & Mucilage canals absent & Centricycas Cantrill \\
\hline 7.1 & Centripetal vascular system absent & 8 \\
\hline 7.2 & Centripetal vascular system present & 11 \\
\hline 8.1 & With canals & 9 \\
\hline 8.2 & With cavities & 10 \\
\hline 9.1 & Cone domes present & Bororoa Petriella \\
\hline 9.2 & Cone domes absent & $\begin{array}{l}\text { Zamuneria Martínez, } \\
\text { Iglesias et Artabe }\end{array}$ \\
\hline 10.1 & Cone domes present & $\begin{array}{l}\text { Brunoa Artabe, Zamuner et } \\
\text { Stevenson }\end{array}$ \\
\hline 10.2 & Cone domes absent & $\begin{array}{l}\text { Sanchucycas Nishida, } \\
\text { Nishida et Tanaka }\end{array}$ \\
\hline 11.1 & Centrifugal vascular system absent & 12 \\
\hline 11.2 & Centrifugal vascular system present & 13 \\
\hline 12.1 & Medullary bundles absent & Fascisvarioxylon Jain \\
\hline 12.2 & Medullary bundles present & $\begin{array}{l}\text { Lioxylon Zhang, Wang, } \\
\text { Saiki, Li et Zheng }\end{array}$ \\
\hline 13.1 & Growth rings present & $\begin{array}{l}\text { Sinocycadoxylon Zhang, } \\
\text { Yang, Fu, Zheng et Wang }\end{array}$ \\
\hline 13.2 & Growth rings absent & 14 \\
\hline 14.1 & Cortical steles absent & 15 \\
\hline 14.2 & Cortical steles present & 16 \\
\hline 15.1 & Cataphylls in vegetative axes present & Menucoa Petriella \\
\hline 15.2 & Cataphylls in vegetative axes absent & $\begin{array}{l}\text { Wintucycas Martínez, } \\
\text { Artabe et Bodnar }\end{array}$ \\
\hline 16.1 & Small medulla and thick cortex & $\begin{array}{l}\text { Neochamberlainia Artabe, } \\
\text { Zamuner et Stevenson }\end{array}$ \\
\hline 16.2 & Wide medulla and thin cortex & $\begin{array}{l}\text { Worsdellia Artabe, } \\
\text { Zamuner et Stevenson }\end{array}$ \\
\hline
\end{tabular}

Fawcett (1989) some of the toxins that characterize cycads could be included in the idioblasts. Developmental, morphological and cytochemical studies indicate that idioblasts may contain specific toxins possibly related to defences against predators (Norstog and Fawcett, 1989; Vovides et al., 1993. For example, all cycad genera except Stangeria have scattered idioblasts within the leaflet interior or on the epidermis, and probably conferring the cycad foliage a measure of immunity to grazing (Vovides, 1991). Also, some species of Zamia, Dioon and Ceratozamia (Cycadales: Zamiaceae) are hosts by aposematic butterflies of the genus Eumaeus Hübner (Lepidoptera). It has been found that some species of this genus sequester substances like cycasin, and then use it as a defence against predators (Castillo-Guevara and Rico-Gray, 2003).

Most of the living gymnosperms are anemophilous; but, many cycads are entomophilous (insect pollinated) (Vovides, 1991; Mound and Terry, 2001; Terry, 2001; Schneider et al., 2002; Proçes and Johnson, 2009). Therefore, interactions with herbivorous insects and/or co-symbionts, the presence of idioblasts, and the predominance of starch in cycad tissues, could form part of a complex pollination syndrome (Norstog and Fawcett, 1989; Vovides et al., 1993). In this context, the abundance of idioblasts and starch in the stems also could have some correspondence with those in the cones, and consecutively with pollination syndrome.

On the other hand, some types of idioblasts in cones could be taxonomically informative (Vovides et al., 1993), and in this sense,
Greguss (1968) describes the absence of secretory idioblasts and the presence of crystals with oxalate of calcium in the rays of Macrozamia.

The presence of idioblasts or secretory structures in stems is also known in several other fossil taxa related to cycads, like Pteridosperms such as Lyginopteris and Medullosa (Steinmann, 1944; Tomescu et al., 2001; Dunn et al., 2003). Even early fossil cycads like Antarcticycas, Michelilloa, Charmorgia and Lyssoxylon have secretory idioblasts in their stems (Archangelsky and Brett, 1963; Gould, 1971; Smoot et al., 1985; Ash, 2001.). Therefore, it seems that the presence and functions of idioblasts could be plesiomorphic, common to a group including early Pteridosperms, and other taxa close to Cycadales.

Then, the occurrence of secretory idioblasts together with many possible starch cells in the stem of Zamuneria amyla could be correlated as a mechanism of defence against herbivores avoiding their starch consumption. Nonetheless, tunnels and galleries bored by animal activity into different tissues of stem clearly demonstrate that the mechanism was not effective against all invaders, especially insect larvae. Alternatively, idioblasts present in the stem also be related to those of the cones and the pollination syndrome.

\subsection{Climate and diversity of cycads in the Cretaceous of Patagonia: the palaeoecological context}

The associated leaf macroflora and wood ring analyses from the Mata Amarilla Formation indicate humid and warm temperate climate with a pronounced seasonality caused by different rainfall patterns (Varela et al., 2015). The paedogenic features, such as mottles, slickensides, nodules and iron/manganese oxide concretions, also support warm temperate climates (Varela et al., 2012b). These climatic conditions can be included in the Warm Temperate Belt in the Cretaceous greenhouse period for the middle latitudes in South America as suggested by Iglesias et al. (2011).

The palaeosol where Zamuneria grew corresponds to vertic Alfisol with moderate to well drained conditions (Varela et al., 2012b), according to the requirements of a well-drained soil for development of some extant cycads (Whitelock, 2002).

The good preservation of the cycad stem is related to the taphonomic conditions promoted by a rapid burial in a fluvial deposit. This sedimentation type (aggradation of the fluvial system) is associated with high sediment supply/accommodation space conditions (Varela et al., 2015).

Zamuneria together with other taxa such as Almargemia Florin, Androstrobus Schimper, Mesodescolea (Archangelsky) emend. Archangelsky et Petriella, Mesosingeria Archangelsky, Pseudoctenis Seward, Restrepophyllum Passalía, Del Fueyo et Archangelsky, Ticoa Archangelsky, and Sueria Menéndez emend. Baldoni depict the diversity of Cycadales in the Cretaceous of South Patagonia (Archangelsky, 1963; Archangelsky and Petriella, 1971; Villar de Seoane, 1997, 2005; Artabe and Stevenson, 1999; Archangelsky and Villar de Seoane, 2004; Cúneo et al., 2010; Passalía et al., 2010).

In addition, Zamuneria has a medullary vascular system (synapomorphy of Encephalarteae), and a centrifugal polyxylic stem, features shared with the extant Encephalarteae. It is important that the tribe Encephalarteae is also monophyletic based on molecular phylogeny (Condamine et al., 2015). If Zamuneria is classified in Encephalarteae, it provides the evidence of the tribe as early as the middle Cenomanian. The absence of the centripetal vascular system and the cortical steles in Zamuneria could be considered as derived characters in the tribe (Artabe et al., 2005), showing higher morphological diversities in the tribe than in Present. To more clearly evaluate character evolution in the cycadales further combined analysis of entire order should be performed. 
This early record of Zamuneria gives us some clues about the diversification of the Encephalarteae across the Cretaceous of Patagonia, probably reaching a peak in the Late Cretaceous, as shown by several taxa in Northern Patagonia (e.g. Neochamberlainia, Wintucycas and Worsdellia) (Artabe et al., 2004, 2005; Martínez et al., 2012). These data agree with the occurrence of the temperate to hot climate proposed for that period (Cladera et al., 2002; Barreda and Archangelsky, 2006; Iglesias et al., 2011), similar to the present climate in Africa and Australia, where the extant Encephalarteae occur. The presence of warm to hot climate elements in the megaflora is in accordance with palynofloras and macrofloras recorded from several Cretaceous strata of Austral and Neuquén Basins (Del Fueyo et al., 2007; Archangelsky and Del Fueyo, 2010; Martínez, 2010, 2012; Martínez and Olivo, 2015; Martínez et al., 2016).

The latest record of cycad stems in Argentina comes from Paleogene strata of Patagonia (Petriella, 1972), and cycad fossil leaves were recently described from Eocene strata of Patagonia (Wilf et al., 2016). The extinction of cycads in Patagonia was apparently driven by the post-Paleogene climatic change (warm and humid to cold and dry conditions), and other factors (e.g. unable to migrate to warmer regions) (Martínez et al., 2012; Martínez and Artabe, 2014), as already documented for the fossil fauna of Antarctica, Patagonian primates and reptiles, and other regions of the world (e.g., La Grand Coupure in France). Like other living forms, including vertebrates, insects and plants, cycads endured in Patagonia until the global cooling event at the late Eocene - early Oligocene (Zachos et al., 2001), being part of what Goin et al. (2010) called the 'Patagonian Hinge'.

\section{Conclusions}

Zamuneria is a new taxon with characters very similar to those of living and fossil Encephalarteae in having manoxylic wood, parenchymatous pith, centrifugal polyxyly and medullary vascular bundles. The centripetal vascular system absent, large amount of parenchyma tissue and idioblasts are remarkable features in this genus, and may be related to some ecological adaptations. This new record suggests an early presence of Encephalarteae in middle Cenomanian.

The process in vegetation dynamics and, consequently, floristic diversity patterns (diversification and extinction of taxa) in Patagonia can be related to the climate change. During most of the Cretaceous, the southern part of South America maintained a warm-temperate climate; a situation that benefited the development of tropical and subtropical taxa (e.g., ferns, cycads, araucarians and palms). The occurrence of several genera of Encephalarteae in the Cretaceous suggests Patagonia as a possible area of early diversification and dispersion across southern continents of Gondwana. Then, the subsequent separation of Gondwana spread the Encephalarteae to other landmasses (South America, Africa and Australia). The other possibility is that the living Encephalarteae were relicts of wider Gondwana distribution.

At present, the genera of Encephalarteae (Encephalartos, Macrozamia and Lepidozamia) are well diversified in Africa and Australia. In contrast, they became extinct in South America, with the last records from Paleogene strata of Patagonia. The extinction of this group in Patagonia was probably influenced by a climatic change (warm and humid to cold and dry conditions), and other factors (e.g., unable to migrate to warmer regions), as one of the victims of the late Eocene global cooling.

The new fossil taxon, Zamuneria amyla gen. et sp. nov., found in Patagonia is another example of the composition of the original Gondwanan flora, providing fossil linking of South America with the living genera of Encephalarteae present in Africa (Encephalartos) and Australia (Macrozamia and Lepidozamia). This record also increases the knowledge of Gondwana Cretaceous floras, and allows us to reconstruct theirs phytogeographical patterns. However, additional studies are needed in several areas of the southern Hemisphere, to help us to better understand the role of cycads in the Mesozoic and Cenozoic ecosystems.

\section{Acknowledgements}

We would like to thanks to the Secretaría de Cultura of Santa Cruz Province, Comisaría, Escuela y Comisión de Fomento from Tres Lagos Town, and landowners C. Waring, Rolón, J. Bertotti, N. Piccinini and F. Nacer for field work permits. To C. Koefoed, P.A. Gallina, and to M. Ferrari for their help and cooperation during fieldwork. We would also like to thank R. Pujana for peels and P. Sarmiento for the technical assistance in the Electron Microscopy Service (FCNyM) at the La Plata Museum. The authors wish to thanks H.A. Carrizo (Fundación Miguel Lillo), A. Crisafulli and V. Espíndola (CECOAL CONICET) for their valuable help and assistance in paleontological collections. The authors are grateful to Eduardo Koutsoukos (Editor in chief) and the two anonymous reviewers for their constructive comments which allowed us to improve this paper.

This research was supported by grants: PICT-2324 (to L.C.A. Martínez) ANPCyT (Agencia Nacional de Promoción Científica y Tecnológica), PICT-0388 (to A. Iglesias), PIP 1016/10 (to D. Poiré) CONICET (Consejo Nacional de Investigaciones Científicas y Técnicas), and 11/N686 (to Analía Artabe) Facultad de Ciencias Naturales y Museo (UNLP).

\section{References}

Archangelsky, S., 1963. Notas sobre la flora fósil de la zona de Ticó, Provincia de Santa Cruz. 2. Tres nuevas especies de Mesosingeria. Ameghiniana 3, 113-122.

Archangelsky, S., Brett, D.W., 1963. Studies on Triassic fossil plants from Argentina. Annals of Botany 27, 147-156.

Archangelsky, S., Del Fueyo, G.M., 2010. Endemism of Early Cretaceous Conifers in Western Gondwana. In: Gee, C.T. (Ed.), Plants in Mesozoic Time: Innovations, Phylogeny, Ecosystems (Ted Delevoryas Festschrift). Indiana University Press, Bloomington, pp. 247-268.

Archangelsky, S., Petriella, B., 1971. Notas sobre la paleoflora fósil de la zona de Ticó, provincia de Santa Cruz. IX. Nuevos datos acerca de la morfología foliar de Mesodescolea plicata Archangeslky (Cycadales, Stangeriaceae). Boletín de la Sociedad Argentina de Botánica XVI $(1,2)$ 88-94.

Archangelsky, S., Villar de Seoane, L., 2004. Cycadean diversity in the Cretaceous of Patagonia, Argentina. Three new Androstrobus species from the Baqueró Group. Review of Palaeobotany and Palynology 131, 1-28.

Artabe, A.E., Stevenson, D.W., 1999. Fossil Cycadales of Argentina. The Botanical Review 65, 219-238.

Artabe, A.E., Zamuner, A.B., Stevenson, D.W., 2004. Two new petrified cycad stems, Brunoa gen. nov. and Worsdellia gen. nov., from the Cretaceous of Patagonia (Bajo de Santa Rosa, Río Negro Province), Argentina. The Botanical Review 70,121-133.

Artabe, A.E., Zamuner, A.B., Stevenson, D.W., 2005. A new genus of Late Cretaceous cycad stem from Argentina, with reappraisal of known forms. Alcheringa 29, 87-100.

Artabe, A.E., Zamuner, A., Stevenson, D.W., 2010. Neochamberlainia, a new name for Chamberlainia Artabe, Zamuner \& D. W. Stev. (Zamiaceae) non Chamberlainia Grout (Brachytheciaceae). Brittonia 62, 95.

Ash, S., 1985. A short thick cycad stem from the Upper Triassic of Petrified Forest National Park, Arizona, and vicinity. Museum of Northern Arizona Bulletin 54, $17-32$.

Ash, S., 2001. New cycadophytes from the Upper Triassic Chinle Formation of the southwestern United States. Paleobios 21, 15-28.

Barreda, V., Archangelsky, S., 2006. The southernmost record of tropical pollen grains in the mid-Cretaceous of Patagonia, Argentina. Cretaceous Research 27, 778-787. Brenner, E.D., Stevenson, D.W., Twigg, R.W., 2003. Cycads: evolutionary innovations and the role of plant-derived neurotoxins. Trends in Plants Science 8, 446-452.

Cantrill, D.J., 2000. A petrified cycad trunk from the Late Cretaceous of the Larsen Basin, Antartica. Alcheringa 24, 307-318.

Castillo-Guevara, C., Rico-Gray, V., 2003. The role of macrozamin and cycasin in Cycads (Cycadales) as antiherbivore defenses. Journal of the Torrey Botanical Society 130, 206-217.

Chamberlain, C.J., 1911. The adult cycad trunk. Botanical Gazette 52, 81-104.

Cladera, G., Andreis, R., Archangelsky, S., Cúneo, R., 2002. Estratigrafía del Grupo Baqueró, Patagonia (provincia de Santa Cruz, Argentina). Ameghinina 39, 3-20.

Condamine, F.L., Nagalingum, N.S., Marshall, C.R., Morlon, H., 2015. Origin and diversification of living cycads: a cautionary tale on the impact of the branching 
process prior in bayesian molecular dating. BMC Evolutionary Biology 15, 65 . http://dx.doi.org/10.1186/s12862-015-0347-8.

Cúneo, N.R., Escapa, I., Villar de Seoane, L., Artabe, A.E., Gnaedinger, S., 2010. Review of the Cycads and Bennettitaleans from the Mesozoic of Argentina. In: Gee, C.T. (Ed.), Plants in Mesozoic Time: Morphological Innovations, Phylogeny, Ecosystems. Indiana University Press, pp. 187-212.

Del Fueyo, G.M., Villar de Seoane, L., Archangelsky, A., Guller, V., Llorens, M., Archangelsky, S., Gamerro, J.C., Musacchio, E.A., Passalía, M., Barreda, V.D., 2007 Biodiversidad de las Paleofloras de Patagonia Austral durante el Cretácico Inferior. Asociación Paleontológica Argentina. Publicación Especial 11. Ameghiniana 50 Años 101-122.

Du, X., Zhu, J., 1982. The emendation of a cycad genus Yuania and the discovery of $Y$. chinensis sp. nov. Memoirs of the Beijing Natural History Museum 17, $1-6$.

Dunn, M.T., Krings, M., Mapes, G., Rothwell, G.W., Mapes, R.H., Keqin, S., 2003. Medullosa steinii sp. nov., a seed fern vine from the Upper Mississippian. Review of Palaeobotany and Palynology 124, 307-324.

Gao, Z., Thomas, B.A., 1989. A review of fossil cycad megasporophylls, with new evidence of Crossozamia Pomel and its associated leaves from the lower Permian of Taiyuan, China. Review of Palaeobotany and Palynology 60, 205-223.

Goin, F.J., Abello, M.A., Chornogubsky, L., 2010. Middle Tertiary marsupials from central Patagonia (early Oligocene of Gran Barranca): understanding South America's Grande Coupure. In: Madden, R.H. (Ed.), The Paleontology of Gran Barranca: Evolution and Environmental Change through the Middle Cenozoic of Patagonia. Cambridge University Press, Cambridge, pp. 69-105.

Gould, R.E., 1971. Lyssoxylon grigsbyi, a cycad trunk from the Upper Triassic of Arizona and New Mexico. American Journal of Botany 58, 239-248.

Greguss, P., 1968. Xylotomy of the living Cycads with a description of their leaves and epidermis. Akadémiai Kiadó, Budapest.

Hermsen, E.J., Taylor, T.N., Taylor, E.L., Stevenson, D.W., 2006. Cataphylls of the Middle Triassic cycad Antarcticycas schopfii and new insights into cycad evolution. American Journal of Botany 93, 724-738.

Hill, K.D., Chase, M.W., Stevenson, D.W., Hills, H.G., Schutzman, B., 2003. The families and genera of cycads: a molecular phylogenetic analysis of Cycadophyta based on nuclear and plastid DNA sequences. International Journal of Plant Science 164, 933-948.

Hill, K.D., Stevenson, D.W., Osborne, R., 2004. The world list of Cycads. The Botanical Review 70, 274-298.

Iglesias, A., Artabe, A.E., Morel, E.M., 2011. The evolution of Patagonian climate and vegetation from the Mesozoic to the present. Biological Journal of the Linnean Society 103, 409-422.

Jain, K.P., 1962. Fascivarioxylon mehtae gen. et sp. nov., a new petrified cycadean wood from the Rajmahal Hills, Bihar, India. The Palaeobotanist 11, 138-143.

Lutz, A.I., Crisafulli, A., Herbst, R., 2003. Vladiloxylon troncosi nov. gen. et sp. (Cycadales) de la Formación La Ternera (Triásico Superior), $3^{\circ}$ Región, Chile. Revista del Museo Argentino de Ciencias Naturales, n.s. 5 31-38.

Mamay, S.H., 1969. Cycads: fossil evidence of Late Paleozoic origin. Science 164, 295-296.

Martínez, L.C.A., 2010. Estudios Xilológicos en el Cretácico de la Cuenca Neuquina, provincia del Neuquén, Argentina (Ph.D. Thesis). Universidad Nacional de La Plata.

Martínez, L.C.A., 2012. Estípite de palmera en el Campaniano del Grupo Neuquén, provincia del Neuquén, Argentina. Ameghiniana 49, 573-584.

Martínez, L.C.A., Artabe, A.E.E., 2014. The fossil cycads of Argentina: new taxa, evidences and relationships about their evolutionary history. $4^{\circ}$ International Palaeontological Congress. Abstract Volume, 572.

Martínez, L.C.A., Olivo, M.S., 2015. Tempskya in the Valanginian of South America (Mulichinco Formation, Neuquen Basin, Argentina) - systematics, palaeoclimatology and palaeoecology. Review of Palaeobotany and Palynology 219, 116-131.

Martínez, L.C.A., Archangelsky, S., Prámparo, M.B., Archangelsky, A., 2016. Early Cretaceous palm pollen tetrads from Patagonia, Argentina. Cretaceous Research 59, 129-139.

Martínez, L.C.A., Artabe, A.E.E., Bodnar, J., 2012. A new cycad stem from the Cretaceous in Argentina and its phylogenetic relationships with other Cycadales. Botanical Journal of the Linnean Society 170, 436-458.

Metcalfe, C.R., Chalk, L., 1979. Anatomy of the Dicotyledons, , second ed.vol. 1. Clarendon Press, Oxford.

Mound, L.A., Terry, I., 2001. Thrips pollination of the Central Australian cycad, Macrozamia macdonnellii (Cycadales). International Journal of Plant Sciences $162,147-154$.

Nagalingum, N.S., Marshall, C.R., Quental, T.B., Rai, H.S., Little, D.P., Mathews, S., 2011. Recent synchronous radiation of a living fossil. Science 334, 796-799.

Nishida, H., Nishida, M., Tanaka, K., 1991. Petrified plants from the Cretaceous of the Kwanto Mountains, Central Japan. III. A polyxylic cycadean trunk, Sanchucycas gigantea gen. et sp. nov. The Botanical Magazine, Tokyo 104 191-205.

Norstog, K.J., Fawcett, P., 1989. Insect cycad symbiosis and its relation to the pollination of Zamia furfuraceae (Zamiaceae) by Rhopalotria mollis (Curculionidae). American Journal of Botany 76, 1380-1394.

Norstog, K.J., Nicholls, T., 1997. The Biology of the Cycads. Cornell University Press, Ithaca.

Osborne, R., Calonje, M., Hill, K.D., Stanberg, L., Stevenson, D.W., 2012. The world list of cycads. Memoirs of the New York Botanical Garden 106, 480-510.

Passalía, M., Del Fueyo, G.M., Archangelsky, S., 2010. An Early Cretaceous zamiaceous cycad of South West Gondwana: Restrepophyllum nov. gen. from Patagonia, Argentina. Cretaceous Research 161, 137-150.
Petriella, B., 1969. Menucoa cazaui nov. gen. et sp., tronco petrificado de Cycadales, prov. de Río Negro, Argentina. Ameghiniana 6, 291-302.

Petriella, B., 1972. Estudio de Maderas Petrificadas del Terciario Inferior del área central de Chubut (Cerro Bororó). Revista del Museo de la Plata (Nueva serie). Sección Paleontología 41, 159-254.

Petriella, B., 1978. Nuevos hallazgos de Cycadales fósiles en Patagonia. Boletín de la Sociedad Latinoamericana de Paleobotánica y Palinología 5, 13-16.

Proçhes, S., Johnson, S.D., 2009. Beetle pollination of the fruit-scented cones of the South African cycad Stangeria eriopus. American Journal of Botany 96, $1722-1730$.

Schneider, D., Wink, M., Sporer, F., Lounibos, P., 2002. Cycads: their evolution, toxins, herbivores and insect pollinators. Naturwissenschaften 89, 281-294.

Smoot, E.L., Taylor, T.N., Delevoryas, T., 1985. Structurally preserved fossil plants from Antacrtica. I. Antacticycas, gen. nov., a Triassic Cycad stem from the Beardmore Glacier Area. American Journal of Botany 72, 1410-1423.

Soltis, D.E., Soltis, P.A., Zanis, M.J., 2002. Phylogeny of seed plants based on evidence from eight genes. American Journal of Botany 89, 1670-1681.

Stevenson, D.W., 1990. Morphology and systematics of the Cycadales. In: Stevenson, D.Wm (Ed.), The Biology, Structure and Systematics of the Cycadales. Memories of the New York Botanical Garden 57, pp. 8-55.

Stevenson, D.W., 1992. A formal classification of the extant cycads. Brittonia 44, 220-223.

Terry, I., 2001. Thrips and weevils as dual, specialist pollinators of the Australian cycad Macrozamia communis (Zamiaceae). International Journal of Plant Sciences 162, 1293-1305.

Tomescu, A.M.F., Rothwell, G.W., Mapes, G., 2001. Lyginopteris royalii from the Upper Mississippian of North America. Review of Palaeobotany and Palynology 116, 159-173.

Varela, A.N., 2015. Tectonic control of accommodation space and sediment supply within the Mata Amarilla Formation (lower Upper Cretaceous) Patagonia, Argentina. Sedimentology 62, 867-869.

Varela, A.N., Richiano, S., Poiré, D.G., 2011. Tsunami vs storm origin for shell bed deposits in a lagoon environment: an example from the Upper Cretaceous of Southern Patagonia, Argentina. Latin America Journal of Sedimentology and Basin Analysis 18, 63-85.

Varela, A.N., Poiré, D.G., Martin, T., Gerdes, A., Goin, F.J., Gelfo, J.N., Hoffmann, S. 2012a. U-Pb zircon constraints on the age of the Cretaceous Mata Amarilla Formation, Southern Patagonia, Argentina: its relationship with the evolution of the Austral Basin. Andean Geology 39, 359-379.

Varela, A.N., Veiga, G.D., Poiré, D.G., 2012b. Sequence stratigraphic analysis of Cenomanian greenhouse palaeosols: a case study from southern Patagonia Argentina. Sedimentary Geology 271-272, 67-82.

Varela, A.N., Iglesias, A., Poiré, D.G., Zamuner, A.B., Richiano, S., Brea, M., 2015 Petrified forests in the Austral Basin marks a Cenomanian forced regression heterogeneous surface. Geobiology. http://dx.doi.org/10.1111/gbi.12169.

Villar de Seoane, L., 1997. Estudio cuticular comparado de nuevas Cycadales de la Formación Baqueró (Cretácico Inferior), Provincia de Santa Cruz, Argentina. Revista Española de Paleontología 12, 129-140.

Villar de Seoane, L., 2005. New cycadalean leaves from the Anfiteatro de Ticó Formation, Early Aptian, Patagonia, Argentina. Cretaceous Research 26, 540-550.

Vovides, A.P., 1991. Cone Idioblasts of Eleven Cycad Genera: morphology, distribution, and significance. Botanical Gazette 152, 91-99.

Vovides, A.P., Norstog, K.J., Fawcett, P.K.S., Duncan, M.W., Nash, R.J., Molsen, D.V., 1993. Histological changes during maturation in male and female cones of the cycad Zamia furfuracea and their significance in relation to pollination biology. Botanical Journal of the Linnean Society 111 (2), 241-252. https://doi.org/10. 1111/j.1095-8339.1993.tb01901.x.

Whitelock, L.M., 2002. The Cycads. Timber Press, Inc, Oregon U.S.A.

Wilf, P., Stevenson, D Wm, Cúneo, R.N., 2016. The last Patagonian cycad, Austrozamia stockeyi gen. et sp. nov., early Eocene of Laguna del Hunco, Chubut, Argentina. Botany 94, 817-829.

Worsdell, W.C., 1896. The Anatomy of the stem of Macrozamia compared with that of other genera of Cycadaceae. Annals of Botany 10, 601-620.

Worsdell, W.C., 1906. The structure and origin of Cycadaceae. Annals of Botany 20, 129-155.

Zachos, J., Pagani, M., Sloan, L., Thomas, E., Billups, K., 2001. Trends, rhythms, and aberrations in global climate 65 Ma to present. Science 292, 686-693.

Zamuner, A.B., Poiré, D.G., Iglesias, A., Larriestra, F., Varela, A.N., 2004. Uppe Cretaceous in situ petrified forest in Mata Amarilla Formation, Tres Lagos, Southern Patagonia, Argentina. Proceedings of the 7th International Organization of Paleobotany Conference, Bariloche 150.

Zgurski, J.M., Rai, H.S., Fai, Q.M., Bogler, D.J., Francisco-Ortega, J., Graham, S.W., 2008 How well do we understand the overall backbone of cycad phylogeny? New insights from a large, multigene plastid data set. Molecular Phylogenetics and Evolution 47, 1232-1237.

Zhang, W., Wang, Y., Saiki, K., Li, N., Zheng, S., 2006. A structurally preserved cycadlike stem, Lioxylon liaoningense gen. et sp. nov., from the Middle Jurassic in Western Liaoning, China. Progress in Natural Science 16, 236-248.

Zhang, W., Yang, X.-J., Fu, X.-P., Zheng, S.-L., Wang, Y.-D., 2012. A polyxylic Cycad trunk from the Middle Jurassic of western Liaoning, China, and its evolutionary implications. Review of Palaeobotany and Palynology 183, 50-60.

Zhu, J.-N., Du, X.-M., 1981. A new cycad-Primocycas chinensis gen. et sp. nov. from the Lower Permian in Shanxi, China, and its significance. Acta Botanica Sinica 23, 401-404. 